OPEN ACCESS

Edited by:

Yuji Morita,

Aichi Gakuin University, Japan

Reviewed by:

Jiri Stulik,

University of Defence, Czechia

Juan M. Tomas,

University of Barcelona, Spain

Monique L. Van Hoek,

George Mason University, United

States

*Correspondence:

Thomas J. Inzana tinzana@vt.edu

Specialty section:

This article was submitted to

Infectious Diseases,

a section of the journal

Frontiers in Microbiology

Received: 11 January 2017

Accepted: 09 May 2017

Published: 30 May 2017

Citation:

Freudenberger Catanzaro KC,

Champion AE, Mohapatra N

Cecere T and Inzana TJ (2017)

Glycosylation of a Capsule-Like

Complex (CLC) by Francisella novicida Is Required for Virulence and Partial

Protective Immunity in Mice.

Front. Microbiol. 8:935

doi: 10.3389/fmicb.2017.00935

\section{Glycosylation of a Capsule-Like Complex (CLC) by Francisella novicida Is Required for Virulence and Partial Protective Immunity in Mice}

\author{
Kelly C. Freudenberger Catanzaro ${ }^{1}$, Anna E. Champion ${ }^{1}$, Nrusingh Mohapatra ${ }^{1}$, \\ Thomas Cecere ${ }^{1}$ and Thomas J. Inzana ${ }^{1,2 *}$
}

${ }^{1}$ Department of Biomedical Sciences and Pathobiology, Center for Molecular Medicine and Infectious Diseases, Virginia-Maryland College of Veterinary Medicine, Virginia Tech, Blacksburg, VA, United States, ${ }^{2}$ Department of Biomedical Sciences, Virginia Tech Carilion School of Medicine, Roanoke, VA, United States

Francisella tularensis is a Gram-negative bacterium and the etiologic agent of tularemia. F. tularensis may appear encapsulated when examined by transmission electron microscopy (TEM), which is due to production of an extracellular capsule-like complex (CLC) when the bacterium is grown under specific environmental conditions. Deletion of two glycosylation genes in the live vaccine strain (LVS) results in loss of apparent CLC and attenuation of LVS in mice. In contrast, F. novicida, which is also highly virulent for mice, is reported to be non-encapsulated. However, the F. novicida genome contains a putative polysaccharide locus with homology to the CLC glycosylation locus in F. tularensis. Following daily subculture of $F$. novicida in Chamberlain's defined medium, an electron dense material surrounding F. novicida, similar to the F. tularensis CLC, was evident. Extraction with urea effectively removed the CLC, and compositional analysis indicated the extract contained galactose, glucose, mannose, and multiple proteins, similar to those found in the F. tularensis CLC. The same glycosylation genes deleted in LVS were targeted for deletion in F. novicida by allelic exchange using the same mutagenesis vector used for mutagenesis of LVS. In contrast, this mutation also resulted in the loss of five additional genes immediately upstream of the targeted mutation (all within the glycosylation locus), resulting in strain F. novicida $\Delta 1212-1218$. The subcultured mutant F. novicida $\Delta 1212-1218$ was CLC-deficient and the CLC contained significantly less carbohydrate than the subcultured parent strain. The mutant was severely attenuated in BALB/c mice inoculated intranasally, as determined by the lower number of $F$. novicida $\Delta$ 1212-1218 recovered in tissues compared to the parent, and by clearance of the mutant by $10-14$ days post-challenge. Mice immunized intranasally with $F$. novicida $\Delta 1212-1218$ were partially protected against challenge with the parent, produced significantly reduced levels of inflammatory cytokines, and their spleens contained only 
areas of lymphoid hyperplasia, whereas control mice challenged with the parent exhibited hypercytokinemia and splenic necrosis. Therefore, F. novicida is capable of producing a CLC similar to that of $F$. tularensis, and glycosylation of the CLC contributed to F. novicida virulence and immunoprotection.

Keywords: Francisella novicida, capsule-like complex, virulence in mice, tularemia, glycosylation, protective immunity

\section{INTRODUCTION}

The Gram-negative, intracellular bacterium Francisella tularensis causes the disease tularemia in numerous animal species and humans (Sjöstedt, 2005). Humans can acquire F. tularensis naturally through the bite of an arthropod vector such as a tick, the inhalation of aerosolized bacteria, the handling of an infected carcass, consumption of contaminated water or food, or laboratory exposure (Dennis et al., 2001; Metzger et al., 2007). Manifestations of tularemia in humans depend on the route of inoculation and the infectious strain. F. tularensis subspecies tularensis (Type A) is responsible for more severe disease, including pneumonic tularemia and potential mortality, whereas subspecies holarctica (Type B) causes less severe disease (Sjöstedt, 2007). Type A isolates are found exclusively in North America and as few as 10 bacterial cells can cause human disease (Saslaw et al., 1961; Sjöstedt, 2007). Both subspecies tularensis and holarctica are considered Tier I Select Agents by the Center for Disease Control and Prevention (CDC) due to their low infectious dose, high level of virulence, and ease of dispersal (Centers for Disease Control and Prevention and Department of Health and Human Services, 2012). The attenuated live vaccine strain (LVS) was derived from $F$. tularensis subspecies holarctica and is exempt from Select Agent regulations (Centers for Disease Control and Prevention and Department of Health and Human Services, 2012). Furthermore, the LVS genome contains multiple mutations and is no longer used as a vaccine candidate due to strain instability and potential virulence for immunocompromised individuals (Conlan and Oyston, 2007).

Several virulence factors of $F$. tularensis, including capsules, lipopolysaccharide (LPS), type IV pili, several secretion systems, outer membrane proteins, the Francisella pathogenicity island, and associated proteins, and others, have been extensively studied and reviewed (Jones et al., 2014; Rowe and Huntley, 2015). Unlike the LPS of enteric Gram-negative bacteria, the LPS of $F$. tularensis does not signal through, and is not an agonist of, tolllike receptor 4 (TLR-4) and has little endotoxic activity (Gunn and Ernst, 2007). Loss of the LPS O-antigen severely attenuates $F$. tularensis in the mouse model and antibodies to the LPS provide some protection against challenge with Type B strains, but not against Type A strains (Li et al., 2007; Raynaud et al., 2007; Modise et al., 2012). F. tularensis strains have also been reported to be encapsulated, based on identification of an electron dense material surrounding the cells by transmission electron microscopy (TEM; Sandström et al., 1988; Cherwonogrodzky et al., 1994; Sjöstedt, 2005; Bandara et al., 2011). Enhanced encapsulation by serial culture of the bacteria in Chamberlain's defined medium (CDM) increases the virulence of LVS for mice
(Cherwonogrodzky et al., 1994). This electron dense capsule is visible by negative staining TEM around F. tularensis Type $\mathrm{A}$ and Type B strains, and is referred to as a large molecular size capsule-like complex (CLC; Bandara et al., 2011). The CLC appears to be a mixture of upregulated proteins, many of which are glycosylated, and are of large molecular size, and distinct from F. tularensis LPS or the O-antigen capsular polysaccharide, which is only visible around the cells when bound to labeled, specific antibodies (Apicella et al., 2010; Bandara et al., 2011; Champion et al., 2015, unpublished data). Daily passage of F. tularensis in CDM broth, followed by culture on CDM agar (CDMA) at about $30^{\circ} \mathrm{C}$ results in enhanced expression of the CLC. In contrast, no detectable CLC is produced in culture supernatant or around the cells when F. tularensis is grown in broth to mid- or late-log phase (Bandara et al., 2011). Deletion of two glycosyltransferase genes in a glycosylation locus distinct from the O-antigen locus in LVS or SchuS4 (Larsson et al., 2005) results in loss of the CLC on the cell surface and attenuation of LVS in mice. Immunization with this deletion mutant (LVS $\Delta 1422-23$ ) also protects mice against lethal challenge with virulent LVS (Bandara et al., 2011).

$F$. tularensis subspecies novicida (referred to here as $F$. novicida) retains a high genetic identity to the more virulent subspecies, is highly virulent for mice, but is only considered virulent for compromised humans (Keim et al., 2007). Unlike subspecies tularensis and holarctica, F. novicida is reported to be non-encapsulated (Sjöstedt, 2005; Elkins et al., 2007; Barker et al., 2009), and does not produce the O-antigen capsule described for LVS (Apicella et al., 2010). Nonetheless, we have identified a locus in F. novicida (FTN_1211-FTN_1221) with substantial homology to the locus involved in CLC glycosylation of F. tularensis (FT0789-FT0800). Therefore, due to the large degree of genetic identity between $F$. novicida and $F$. tularensis ( 97\%; Kingry and Petersen, 2014), the lack of mutations in wildtype $F$. novicida (as there are in LVS), and that $F$. novicida is as virulent as type A F. tularensis for the mouse (the most common model for studying tularemia), but relatively easy to modify genetically, clarifying the presence and role of the CLC in F. novicida will aid in clarifying its role as a virulence factor in type A F. tularensis. In this investigation we showed that when $F$. novicida was grown under conditions that enhance expression of the CLC in F. tularensis (Bandara et al., 2011), an electron dense material was also detected surrounding F. novicida. A F. novicida mutant was generated that lacked multiple genes within the glycosylation locus (FTN_1212-1218). This mutant was CLC-deficient, attenuated in a mouse model of tularemia, and the live mutant provided limited protection to mice against challenge with wild-type $F$. novicida. 


\section{MATERIALS AND METHODS}

\section{Bacterial Strains and Growth Conditions}

The bacterial strains and plasmids used in this study are listed in Table 1. Francisella strains were grown on Chamberlain's defined medium agar (CDMA; Chamberlain, 1965) or brain heart infusion agar (BD, Franklin Lakes, N.J.) containing $0.1 \%$ cysteine (BHI-C) at $37^{\circ} \mathrm{C}$ with $6 \% \mathrm{CO}_{2}$. Broth cultures of Francisella strains were grown in Chamberlain's defined medium broth (CDMB; Chamberlain, 1965) or BHI-C broth with shaking $(175-200 \mathrm{rpm})$ at $37^{\circ} \mathrm{C}$, unless otherwise indicated. Type A strain TI0902 was grown in the CDC-certified BSL-3 laboratory at the Center for Molecular Medicine and Infectious Diseases (CMMID). For enhanced expression of any potential CLC, all Francisella strains were subcultured daily in CDMB for 10 days (identified by extension name_P10), and then grown on CDMA for 5 days at $30-32^{\circ} \mathrm{C}$ with $\sim 6 \% \mathrm{CO}_{2}$, as described (Bandara et al., 2011). Escherichia coli strains were grown at $37^{\circ} \mathrm{C}$ in LuriaBertani (LB) broth or on LB agar (BD). Antibiotics included for growth of recombinant $F$. novicida and $E$. coli strains were 20 and $50 \mu \mathrm{g} / \mathrm{ml}$ of kanamycin, or 250 and $100 \mu \mathrm{g} / \mathrm{ml}$ of hygromycin, respectively.

\section{Blast Analysis of the F. novicida Genome}

The presence of a putative glycosylation locus distinct from the $\mathrm{O}$-antigen locus in F. novicida was searched for using BLAST (Altschul et al., 1990) using the F. tularensis Type A SchuS4 glycosylation locus (FTT_0789 to FTT_0800) for comparison.

\section{Mutagenesis of $\boldsymbol{F}$. novicida}

Suicide plasmid pSC-1423/1422K, which was used for mutagenesis of LVS, was also used for mutagenesis of $F$. novicida by allelic exchange, targeting FTN_1212 and FTN_1213 (Bandara et al., 2011). Plasmid DNA was purified from E. coli using the QIAprep Spin Miniprep Kit (QIAGEN, Valencia, $\mathrm{CA})$. The chemical transformation protocol used to introduce pSC-1423/1422K into F. novicida was based on a combination of previously described methods (Frank and Zahrt, 2007; Gallagher et al., 2008). An overnight culture of F. novicida grown on CDMA was suspended in $1 \mathrm{ml}$ of phosphate buffered saline (PBS), pH 7.6. Approximately $100 \mathrm{ng}$ of the plasmid DNA and $100 \mu \mathrm{l}$ of the bacteria in PBS were added to $1 \mathrm{ml}$ of transformation buffer $(0.04 \%$ L-arginine, $0.04 \% \mathrm{~L}$-aspartic acid, $0.02 \%$ L-histidine, $0.04 \%$ DL-methionine, $0.004 \%$ spermine phosphate, $1.58 \%$ sodium chloride, $0.294 \% \mathrm{CaCl} 2$, and $0.6 \%$ Trizma base). This suspension was incubated at $37^{\circ} \mathrm{C}$ with slow agitation (100 rpm) for $1 \mathrm{~h}, 2 \mathrm{ml}$ of CDMB was added, and incubation continued for $4-6 \mathrm{~h}$ with shaking at $200 \mathrm{rpm}$. Various concentrations of the culture were inoculated to selective $\mathrm{BHI}-\mathrm{C}$ agar and incubated at $37^{\circ} \mathrm{C}$ in $6 \% \mathrm{CO}_{2}$ for up to 5 days. Kanamycin-resistant colonies were screened for the correct insertion by PCR, and one mutant was confirmed to contain a deletion spanning at least FTN_1212 and FTN_1213 by a second round of PCR and by reverse transcriptase PCR (RT-PCR). To our surprise, subsequent analysis by PCR and RT-PCR indicated that in addition to FTN_1212-1213, the additional open reading frames (ORFs) FTN_1214-1218, which all reside within this putative glycosylation locus, were also absent. Therefore, the mutant was named $F$. novicida $\Delta 1212-1218$.

\section{PCR and DNA Sequencing}

A typical PCR reaction consisted of $1 x$ PCR HIFI SuperMix (Invitrogen), $0.02 \mu \mathrm{g}$ genomic DNA as template, and $0.4 \mu \mathrm{M}$ of each oligonucleotide primer in $50 \mu \mathrm{l}$ of reaction mixture. The PCR cycling parameters used were $94^{\circ} \mathrm{C}$ for 2 min followed by 35 cycles of $94^{\circ} \mathrm{C}$ for $30 \mathrm{~s}, 52^{\circ} \mathrm{C}$ for $30 \mathrm{~s}$, and $68^{\circ} \mathrm{C}$ for $2 \mathrm{~min}$, and an additional extension for $5 \mathrm{~min}$ at $68^{\circ} \mathrm{C}$. For sequencing of the putative CLC glycosylation locus the forward primer was FTN_1219_F and the reverse primer was FTN_1210_R (Table S1). Amplicons from LVS, F. novicida U112, and the mutant strain were sequenced using FTN_1219_forward and FTN_1210_reverse primers at the Biocomplexity Institute at Virginia Tech using the ABI 3730 sequencer. Sequence files were analyzed using NCBI nucleotide BLAST online program (Altschul et al., 1990).

\section{Reverse Transcriptase-PCR (RT-PCR)}

RNA was isolated from $F$. novicida and F. novicida $\Delta 1212-$ 1218 using the RNeasy Mini Kit (Qiagen). cDNA was generated using the SuperScript III First-Strand (ThermoFisher) synthesis system (Invitrogen) following the manufacturer's instructions. The primers used to amplify cDNA of genes FTN_1211 to FTN_1221 for RT-PCR are listed in Table S1.

\section{Purification of the Putative CLC}

F. novicida was grown in CDMB to just past mid-log phase, subcultured consecutively in fresh medium 10 times daily, and then grown on CDMA for 5 days at $32^{\circ} \mathrm{C}$ with $\sim 7 \% \mathrm{CO}_{2}$ to obtain strain F. novicida_P10. The strain was then extracted with $0.5 \%$ phenol as previously described (Bandara et al., 2011) and by a modified method using urea (Champion et al., 2015). Briefly, the bacteria were scraped off 10 agar plates and suspended in $\sim 100 \mathrm{ml}$ of $1 \mathrm{M}$ urea. This suspension was incubated at room temperature for $15 \mathrm{~min}$ and sedimented by centrifugation at $10,000 \times \mathrm{g}$ for $15 \mathrm{~min}$. The supernatant was subjected to ultracentrifugation at $40,000 \times \mathrm{g}$ for $4 \mathrm{~h}$ to overnight, and the subsequent supernatant was dialyzed through a membrane with a pore size of $50,000 \mathrm{kDa}$ in $10 \mathrm{mM}$ HEPES and $0.1 \%$ sodium dodecyl sulfate (SDS) twice, followed by dialysis in 10 $\mathrm{mM}$ HEPES once. Sodium acetate $(30 \mathrm{mM}$ final) was added to the dialyzed liquid, followed by addition of 3-5 volumes of $95 \%$ ethanol, and the mixture incubated overnight at $-20^{\circ} \mathrm{C}$ to precipitate any large molecular size material. The precipitate was sedimented by centrifugation at $10,000 \times \mathrm{g}$ for $30 \mathrm{~min}$ and resuspended in $\sim 25 \mathrm{ml}$ of buffer containing $50 \mathrm{mM}$ Trizma base, $10 \mathrm{mM} \mathrm{CaCl}$, $10 \mathrm{mM} \mathrm{MgCl}_{2}$, and $0.05 \%$ sodium azide. Ten microliters of RiboShredder ${ }^{\mathrm{TM}}$ RNase Blend (Epicenter, Madison, WI) and $25 \mu \mathrm{g} / \mathrm{ml}$ of DNase were added, the solution incubated at $37^{\circ} \mathrm{C}$ overnight, and the mixture extensively dialyzed through a $50,000 \mathrm{kDa}$ membrane in $4 \mathrm{~L}$ of distilled water ( $4-5$ changes). Any large molecular size material in the retentate was precipitated with ethanol, as above, and lyophilized. Any putative CLC from other strains and mutants that were subcultured in CDMB was extracted in the same manner. 
TABLE 1 | Bacterial strains used in this study.

\begin{tabular}{|c|c|c|}
\hline Strain/Plasmid & Description & Source \\
\hline F. novicida & U112 wild type strain & Dr. Karen Elkins \\
\hline F. novicida_P10 & F. novicida subcultured 10 times in CDMB & This work \\
\hline F. novicida $\Delta 1212-1218 \_P 10$ & F. novicida $\Delta 1212-1218$ subcultured 10 times in CDMB & This work \\
\hline tnfn1_pw060328p06q149 & F. novicida strain with a T20 transposon insertion in FTN_1214 & Gallagher et al., 2007 \\
\hline tnfn1_pw060323p05q110 & F. novicida strain with a T20 transposon insertion in FTN_1215 & Gallagher et al., 2007 \\
\hline tnfn1_pw060420p04q184 & F. novicida strain with a T20 transposon insertion in FTN_1216 & Gallagher et al., 2007 \\
\hline tnfn1_pw060418p03q107 & F. novicida strain with a T20 transposon insertion in FTN_1217 & Gallagher et al., 2007 \\
\hline tnfn1_pw060323p07q127 & F. novicida strain with a T20 transposon insertion in FTN_1218 & Gallagher et al., 2007 \\
\hline E. coli Top10 & $\begin{array}{l}\text { Genotype: } \mathrm{F}-\text { mcrA } \Delta(\text { mrr-hsdRMS-mcrBC) } \Phi 80 / a c Z \Delta \mathrm{M} 15 \Delta \text { lacX74 recA1 araD139 } \\
\Delta(\text { araleu }) 7697 \text { gal } \cup \text { galK rpsL (StrR) endA1 nupG }\end{array}$ & Invitrogen \\
\hline pSC-1423/1422K & $\begin{array}{l}\text { Francisella suicide vector containing flanking regions to FTL_1423-22 with kanamycin } \\
\text { resistance }\end{array}$ & Bandara et al., 2011 \\
\hline pMP822 & Hygromycin resistant E. coli/Francisella shuttle vector with a blab promoter & LoVullo et al., 2009 \\
\hline pMP_FTN1212-1213 & pMP822 with FTN1212-1213 inserted downstream of the blab promoter & This work \\
\hline
\end{tabular}

\section{TEM}

Francisella strains were subcultured in CDMB and finally on CDMA, as described above, to enhance expression of CLC, or grown in BHI-C broth with shaking to minimize CLC production. TEM of the bacteria was carried out as previously described (Bandara et al., 2011). Briefly, the bacteria were gently suspended and fixed in $0.1 \mathrm{M}$ sodium cacodylate buffer with $2.5 \%$ glutaraldehyde, and incubated with end-over-end rotation at room temperature for $2 \mathrm{~h}$. The suspension was allowed to adhere to formvar-coated grids for $5 \mathrm{~min}$ and then stained with $0.5 \%$ uranyl acetate. The grids were briefly washed with distilled water, dried, and the bacteria viewed on a Jeol JEM-1400 electron microscope. Type A strain TI0902 was subcultured in CDMB as described above, fixed in $0.1 \mathrm{M}$ sodium cacodylate buffer with $2.5 \%$ glutaraldehyde, and incubated with end-over-end rotation at room temperature for $2 \mathrm{~h}$ before being stored at $4{ }^{\circ} \mathrm{C}$ for 5 days. A sample was inoculated onto CDMA and allowed to incubate for 5 days at $37^{\circ} \mathrm{C}$ to ensure complete loss of bacterial viability before the cells were processed as described above.

\section{Compositional Analysis of the Putative CLC}

The carbohydrate composition of the F. novicida_P10 extract was determined by combined gas chromatography-mass spectrometry (GC/MS) at the University of Georgia Complex Carbohydrate Research Center, as previously described (Merkle and Poppe, 1994; Bandara et al., 2011).
Crude urea extracts were used to compare the relative amounts of protein and/or carbohydrate present in the putative CLC from $F$. novicida_P10, F. novicida $\Delta$ 1212-1218_P10, and each transposon (Tn) mutant with single mutations in FTN_1212, FTN_1213, FTN_1214, FTN_1215, FTM_1216, FTN_1217, FTN_1218 that were subcultured on CDM 10 times to enhance surface expression of CLC. Colonies from individual plates were suspended in $4 \mathrm{ml}$ of $1 \mathrm{M}$ urea and incubated at room temperature for $15 \mathrm{~min}$. The bacteria were sedimented by centrifugation at $10,000 \times \mathrm{g}$ for $15 \mathrm{~min}$, and the supernatant was carefully removed for further analysis. Pelleted cells were used to determine the wet weight of bacteria for each crude extract. The amount of protein and carbohydrate/g of bacterial wet weight of the $1 \mathrm{M}$ urea extract was determined using the Pierce ${ }^{\mathrm{TM}}$ BCA Protein Assay Kit (Thermo Scientific, Waltham, MA), and anthrone assay (Scott and Melvin, 1953), respectively.

\section{Electrophoretic Profile of the Putative CLC}

Electrophoretic profiles were resolved on $\mathrm{NuPAGE}^{\circledR}$ Novex ${ }^{\circledR} 4-12 \%$ Bis-Tris Protein Gels (Life Technologies) by electrophoresis at a constant voltage of $200 \mathrm{v}$ for $\sim 40 \mathrm{~min}$. Gels were stained with the Pierce Silver Stain Kit (Thermo Scientific), or $0.25 \%$ Stains-All (SigmaAldrich, St. Louis, MO; Bandara et al., 2011), or both. 


\section{Virulence and Protective Efficacy of $F$. novicida $\Delta 1212-1218$ in Mice}

Female BALB/c mice 6-8 weeks old (Charles River Laboratories, Wilmington, MA) were housed in an AALAC-accredited ABSL2 facility. Groups of 7-8 mice were used to assess the virulence of $F$. novicida $\Delta 1212-1218$ compared to the parent strain. Mice were anesthetized with 3-4\% isofluorane and inoculated intranasally (IN) with 50,100,1,000, or 10,000 CFU of F. novicida $\Delta 1212-1218 /$ mouse, or $1,000 \mathrm{CFU}$ of $F$. novicida ( $>100 \mathrm{X}$ the $\mathrm{LD}_{50}$ )/mouse (Kieffer et al., 2003; Lauriano et al., 2004; Cong et al., 2009), determined spectrophotometrically, in $20 \mu \mathrm{l}$ of PBS. All inoculation doses were confirmed by viable plate count on BHI-C agar. Mice were monitored daily, scored for health status, and weighed daily after inoculations. Moribund mice were euthanized with excess $\mathrm{CO}_{2}$ and lungs, liver, and spleen were collected. Some mice were euthanized at 1, 3, 6, 10, and 14 days post-challenge. The number of bacteria in the liver, lungs, and spleen were determined by viable plate count of weighed, homogenized tissues.

Groups of four mice each were immunized IN with various doses of $F$. novicida $\Delta 1212-1218$ (50, 100, 1,000, or 10,000 CFU/mouse) in $20 \mu \mathrm{l}$ of PBS or PBS alone. Six weeks after immunization the mice were challenged IN with 1,000 CFU of $F$. novicida. All mice were monitored for 14 days and then euthanized. Any animals that became moribund prior to day 14 post-challenge were euthanized immediately. Tissues were harvested from all mice and cultured to determine bacterial numbers from each inoculation group.

\section{Histopathology of Spleen Samples}

Spleen samples were sent to the histopathology laboratory at the Virginia-Maryland College of Veterinary Medicine (VMCVM) for preparation and staining. Briefly, sections of spleen were fixed in $10 \%$ neutral buffered formalin, processed, and embedded in paraffin. Sections were stained with hematoxylin and eosin (H\&E), read with an Olympus BX43 microscope, and photomicrographs were taken with an Olympus DP73 digital camera and cellSens software.

\section{Cytokine Analyses}

Spleen tissues from the challenged mice were lysed using the BioPlex Cell Lysis Kit according to the manufacturer's instructions (Bio-Rad). The Pierce ${ }^{\mathrm{TM}}$ BCA Protein Assay Kit (Thermo Scientific) was used to determine the total protein level of each lysate for standardization of samples. Lysates were analyzed in triplicate using the Bio-Plex Pro ${ }^{\mathrm{TM}}$ Mouse Cytokine Th1/Th2 Assay (Bio-Rad, Hercules, CA) following the manufacturer's instructions.

\section{Statistical Analyses}

Student's $T$-test was used to evaluate significant differences in the carbohydrate and protein composition of the putative CLC from F. novicida_P10 and F. novicida $\Delta 1212-1218 \_$P10. The carbohydrate content of subcultured $F$. novicida transposon mutants corresponding to each gene affected in the $F$. novicida $\Delta 1212-1218$ strain was compared to the subcultured parent strain using One-Way ANOVA. The Mantel-Cox log-rank test was used to compare the survival curves of the control and immunized mice following challenge. Multiple T-tests using the Holm-Sidak method for correcting multiple comparisons was used to assess differences in bacterial load in mice inoculated with $F$. novicida or $F$. novicida $\Delta 1212-1218$. One-way ANOVA was also used to evaluate significance in bacterial loads and cytokine levels of immunized mice compared to control mice. Tukey's post-hoc test was used after the completion of the one-way ANOVA to identify specific differences between the bacterial loads and cytokine levels of inoculation groups. Statistical analyses were determined using GraphPad Prism 6 (GraphPad Software Inc., La Jolla, CA).

\section{RESULTS}

\section{Extraction of Putative CLC from F. novicida}

Following serial passage of F. novicida strain U112 in CDMB and growth on CDMA for 5 days at $32^{\circ} \mathrm{C}$, aggregates of an electron dense material were identified around the bacteria following negative staining and TEM (Figure 1C). The electron dense material surrounding F. novicida_P10 was similar to the aggregated material observed surrounding F. tularensis Type A strain TI0902_P10 (Figure 1A) and F. tularensis Type B strain LVS_P10 (Bandara et al., 2011). As reported for LVS (Bandara et al., 2011), F. novicida cells that were grown to mid-log phase in $\mathrm{BHI}-\mathrm{C}$ broth at $37^{\circ} \mathrm{C}$ did not produce a visible electron dense material (Figure 1B).

The putative CLC from F. novicida_P10 was extracted as described in methods using $1 \mathrm{M}$ urea in place of $0.5 \%$ phenol (Bandara et al., 2011). The use of urea improved solubility and diminished CLC aggregation for type A and B strains (Champion et al., 2015), which was problematic with the CLC extracted with phenol (Bandara et al., 2011). The electrophoretic profiles of $F$. novicida_P10 soluble fraction extracts using urea vs. phenol were similar (Figure 2C) and were similar to the profile of the CLC from LVS_P10, although the extracts stained poorly with only silver stain (Figure 2A). Of particular note were the similarities of the large molecular size band from the F. novicida_P10 extract (Figure 2A, lanes 2 and 3) and the F. tularensis LVS_P10 CLC (Figure 2A, lane 1). As previously shown with the CLC from LVS and type A strains (Bandara et al., 2011; Champion et al., 2015), a wide variety of proteins were isolated from both the crude and the enzyme-digested $F$. novicida_P10 extracts. The putative CLC proteins could be further divided into soluble and insoluble portions based on their solubility in water, but the large molecular size smear $(\sim 250 \mathrm{kDa})$ was present in only the soluble portion of the F. novicida_P10 extract and was highly visible using the cationic dye Stains-all (Figure 2B). Selective staining with Stains-All further supported that the material at $\sim 250 \mathrm{kDa}$ contained carbohydrate (stained blue), which is likely why the material stained poorly with only silver stain and appeared as a smear in the gels. GC-MS indicated that the carbohydrate portion of the putative CLC was composed of glucose and galactose in equal amounts, and less of mannose, which is identical to the glycoses identified in the LVS CLC (Bandara et al., 2011). 

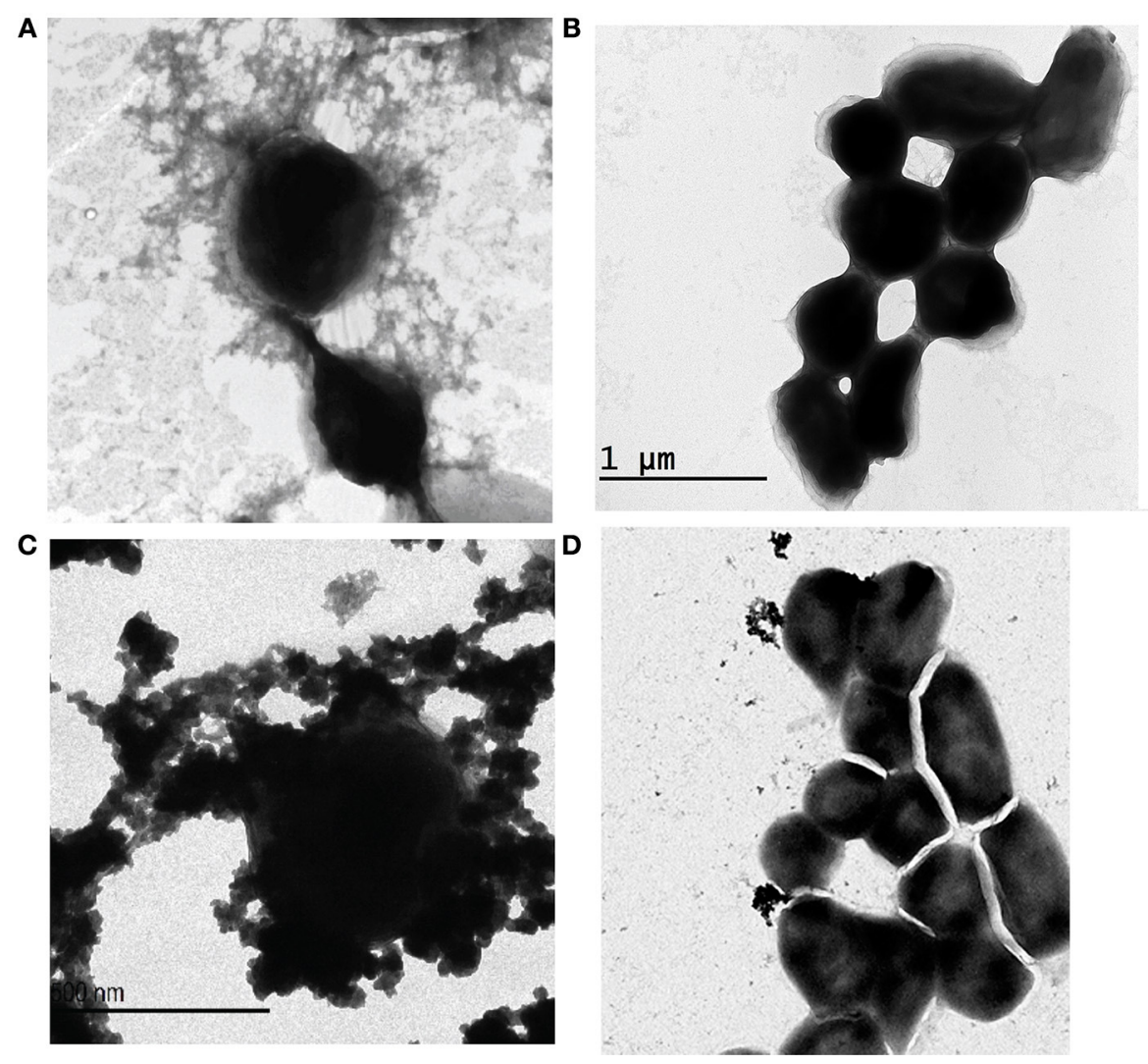

FIGURE 1 | Electron micrographs of Francisella subspecies and glycosyltransferase mutants. Bacterial cells were negatively stained with uranyl acetate and examined by TEM. Francisella strains were subcultured in $\mathrm{CDMB}(\mathbf{A}, \mathbf{C}, \mathbf{D})$ for 10 consecutive days and then grown for 5 days at $32^{\circ} \mathrm{C}$ on $\mathrm{CDMA}$ for 5 days to enhance CLC expression. F. novicida grown in BHI-C broth with shaking to mid-log phase did not express this electron dense material (B). F. novicida cells grown to enhance CLC expression (C) were surrounded by a similar electron dense material as that produced by F. tularensis Type A grown to enhance CLC expression (A). The glycosyltransferase mutant F. novicida $\Delta 1212-1218$ P10 (D) produced little of the electron dense material, but what material was present was not closely associated with the cell surface. Micrographs shown are representative of most fields. Scale bars represent $500 \mathrm{~nm}$.

\section{Mutagenesis of the Putative CLC Glycosylation Locus and Reduction of the Carbohydrate Content in CLC Extracts}

A DNA region in the genome of $F$. novicida $\mathrm{U} 112$ with homology to the LVS CLC glycosylation locus (Bandara et al., 2011) was identified by BLAST analysis (Table 2). The glycosylation locus in F. tularensis is comprised of 12 open reading frames (ORF), whereas the F. novicida locus contained 11 ORFs (Figure 3B). The F. novicida locus did not contain homologs to FTL_1425, FTL_1426, and FTL_1427, but did contain two alternate genes (FTN_1215 $[k p s C]$ and FTN_1216) that are not found in F. tularensis. F. novicida did contain homologs to two genes required for CLC glycosylation in LVS (Bandara et al., 2011) and glycosylation of DsbA in type A F. tularensis (Thomas et al., 2011). These two genes (FTN_1212 and FTN_1213) were targeted for deletion in F. novicida to determine if they were also responsible for CLC glycosylation in F. novicida. Two genes were mutated because we previously showed that deletion of one gene (of two separate genes) in this locus failed to adequately delete glycosylation (Bandara et al., 2011).
FTN_1212 and FTN_1213 were successfully deleted from F. novicida using allelic exchange with suicide plasmid pSC$1422 / 23 \mathrm{~K}$, as determined by amplification of the kanamycin resistance cassette and failure to amplify the targeted region by PCR or RT-PCR. However, RT-PCR of FTN_1212 and FTN_1213 and the remaining genes in this locus indicated that ORFs FTN_1212 through FTN_1218 were not expressed, but cDNA was amplified from the first (upstream) three genes in the locus: FTN_1219 to FTN_1221 and the gene downstream of the targeted mutation, FTN_1211, indicating the mutation was not polar and was restricted to the glycosylation locus (Figure 4B). Each of these genes in the parent were expressed normally (Figure 4A). Furthermore, PCR of each of the individual genes within the locus amplified FTN_1211 and FTN_1219-1221, but failed to amplify DNA from FTN_1212-1218, indicating that the allelic exchange mutation affected seven genes rather than only the two target genes (Figure 5). This mutant was named $F$. novicida $\Delta 1212-1218$. DNA sequencing of the entire locus showed that 100-bp of FTN_1219, all of FTN_12181213, and 210-bp of FTN_1212 were deleted and replaced with the kanamycin resistance gene (Figure 3B), confirming 


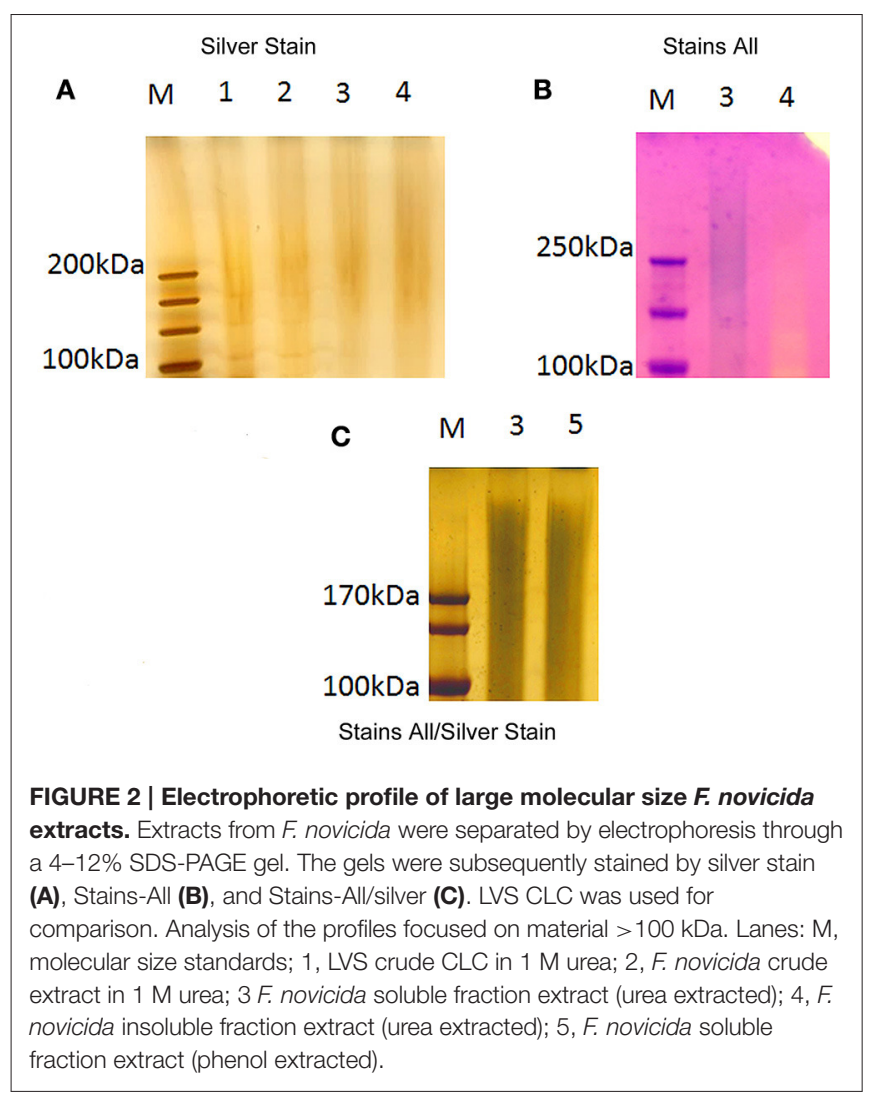

that FTN_1212-1218 were not functional (data not shown). Needleman-Wunsch global alignment of the glycosylation locus of LVS compared to F. novicida indicated there was 96-99\% identity in 9 out of 12 genes present in the two loci (Figure 3A). Three LVS genes (FTL_1425-27) were missing in F. novicida, while two additional genes ( $k p s C$ and FTN_1216) were present exclusively in the locus of $F$. novicida (Figure 3A). DNA sequence analysis of the entire $F$. novicida glycosylation locus identified 1,019 nucleotides spanning FTN_1218 and FTN_1219 that shared 51\% identity with the targeted region in FTL_1424 that flanks the LVS mutagenesis vector (Figure 3B, red line) where a recombination event occurred (not shown).

F. novicida $\Delta 1212-1218$ and each of the $7 F$. novicida transposon (TN) mutants with a single TN-interrupted gene in FTN_1212-1218 were subcultured ten times in CDMB to enhance any CLC material they were capable of making. The majority of F. novicida $\Delta 1212-1218$ _P10 cells lacked any surface material around them, but some small amounts of putative CLC was observed by TEM surrounding F. novicida $\triangle 1212-$ 1218_P10. In contrast, the majority of the subcultured, $F$. novicida $\Delta 1212-1218 \_$P10 cells lacked any surface material around them. Furthermore, what surface material was present was not closely associated to the cells (Figure 1D), as it was on the surface of F. novicida_P10 (Figure 1C). The amount of protein in the extract from $F$. novicida $\Delta 1212-1218 \_$P10 was not significantly different from that found on F. novicida_P10, but the carbohydrate content of the putative CLC extract from F. novicida $\Delta 1212-1218 \_\mathrm{P} 10$ was significantly lower $(p=0.02$;
Figure 6), even though the LPS was not affected. However, the amount of carbohydrate present in the CLC from each of the subcultured isogenic TN mutants was not significantly different $(p>0.05)$ from that of the subcultured parent strain (Table S2). Therefore, mutagenesis of a single gene within this glycosylation locus was inadequate to significantly affect CLC glycosylation, as previously reported (Bandara et al., 2011).

\section{Attenuation of $F$. novicida $\Delta 1212-1218$ in Mice}

Female BALB/c mice were inoculated IN with $F$. novicida or $F$. novicida $\Delta 1212-1218$ to determine if the lack of glycosylation affected virulence. All mice challenged with up to $10,000 \mathrm{CFU}$ of $F$. novicida $\Delta 1212-1218$ IN survived the study duration of 14 days with minimal to no clinical signs (Figure 7D). Some groups of mice were inoculated with 1,000 CFU of $F$. novicida or $F$. novicida $\Delta 1212-1218 \mathrm{IN}$ and humanely euthanized at days 1,3 , 6,10 , and 14 . The bacterial burden in the lungs (Figure 7A), liver (Figure 7B), and spleen (Figure 7C) increased significantly from days 1 to 3 in mice infected with $F$. novicida compared to mice challenged with $F$. novicida $\Delta 1212-1218(p=0.0021,0.0005$, and $<0.0001$, respectively). Mice infected with $F$. novicida did not survive beyond 3 days post-challenge. Bacterial burdens on day 1 in the lungs, liver, and spleen of mice infected with $F$. novicida $\Delta 1212-1218$ were below the level of detection. Bacterial burdens in the lungs (Figure 7A) and spleen (Figure 7B) were detected on day 3 , but were significantly lower $(p=0.0018$ and $>0.001$ respectively) than bacterial numbers detected on day 3 in mice infected with $F$. novicida. F. novicida $\Delta 1212-1218$ was detected in the liver on day 6, but not at other time points (Figure 7C). F. novicida $\Delta 1212-1218$ was undetectable in any organs of the mice by day 14 post-challenge. Therefore, F. novicida $\Delta 1212-1218$ was unable to multiply and disseminate in mice as efficiently as $F$. novicida and was significantly attenuated following challenge by the IN route of infection compared to F. novicida $(p=0.0183)$. Mice inoculated with $10,000 \mathrm{CFU}$ of $F$. novicida $\Delta 1212-1218$ also had significantly less weight loss than mice inoculated with 1,000 CFU of F. novicida at 1,3 , and 4 days post-inoculation $(p<0.005$; Figure S1).

\section{Protective Efficacy of $F$. novicida $\Delta 1212-1218$ against Challenge with the Parent Strain}

$\mathrm{BALB} / \mathrm{c}$ mice were immunized with PBS or variable doses of F. novicida $\Delta 1212-1218(50,100,1,000$, and 10,000 CFU) IN. Six weeks after immunization the mice were challenged IN with $1,000 \mathrm{CFU}$ of $F$. novicida, monitored for 2 weeks, and the survival of each group recorded (Figure 8A). All control mice became moribund between days 3 and 4 and were euthanized. All groups of immunized mice developed clinical symptoms following challenge with the parent strain and no group had 100\% survival by day 14 . Mice that developed more severe clinical symptoms, including hunched appearance and closed eyes, did not recover and were euthanized when the mice became moribund. Mice that experienced milder symptoms including slightly ruffled fur and some weight loss recovered by day 14 , which included some 
TABLE 2 | CLC glycosylation locus in $F$. tularensis subspecies.

\begin{tabular}{|c|c|c|c|c|c|}
\hline $\begin{array}{l}\text { F. tularensis subsp. } \\
\text { novicida ORF }\end{array}$ & Size (bp) & Protein product ${ }^{\mathrm{a}}$ & $\begin{array}{l}\text { F. tularensis subsp. } \\
\text { holarctica LVS ORF }\end{array}$ & $\begin{array}{l}\text { F. tularensis subsp. } \\
\text { tularensis schuS4 ORF }\end{array}$ & $\begin{array}{c}\% \text { Sequence Identity } \\
\text { to type A }\end{array}$ \\
\hline FTN_1221 & 669 & D-ribulose-phosphate 3-epimerase & FTL_1432 & FTI_0789 & 98 \\
\hline FTN_1219 & 1020 & UDP-glucose 4-epimerase & FTL_1430 & FTT_0791 & 97 \\
\hline FTN_1218 & 1230 & Glycosyltransferase & FTL_1429 & FTI_0792 & 97 \\
\hline FTN_1217 & 1689 & ATP-binding membrane transporter & FTL_1428 & FTI_0793 & 98 \\
\hline Not present & 684 & Hypothetical protein & FTL_1426 & FTT_0795 & NA \\
\hline Not present & 762 & Hypothetical protein & FTL_1425 & FIT_0796 & NA \\
\hline FTN_1216 & 744 & $\begin{array}{l}\text { Hypothetical protein with } \\
\text { methyltransferase domain }\end{array}$ & Not present & Not present & NA \\
\hline FTN_1215 & 1161 & $\begin{array}{l}\text { Capsule polysaccharide export } \\
\text { protein }\end{array}$ & Not present & Not present & NA \\
\hline FTN_1211 & 663 & Haloacid dehalogenase & FTL_1421 & FTT_0800 & 98 \\
\hline
\end{tabular}

${ }^{a} F$. novicida homologs to the F. tularensis Type A and LVS CLC glycosylation locus. Two genes are present in F. novicida that are not found in the F. tularensis locus. There are three genes in the F. tularensis CLC glycosylation locus that are not present in the F. novicida locus: FTTO794, FITO795, and FIT0796; all three genes encode for hypothetical proteins. ${ }^{b}$ NA, Not applicable.
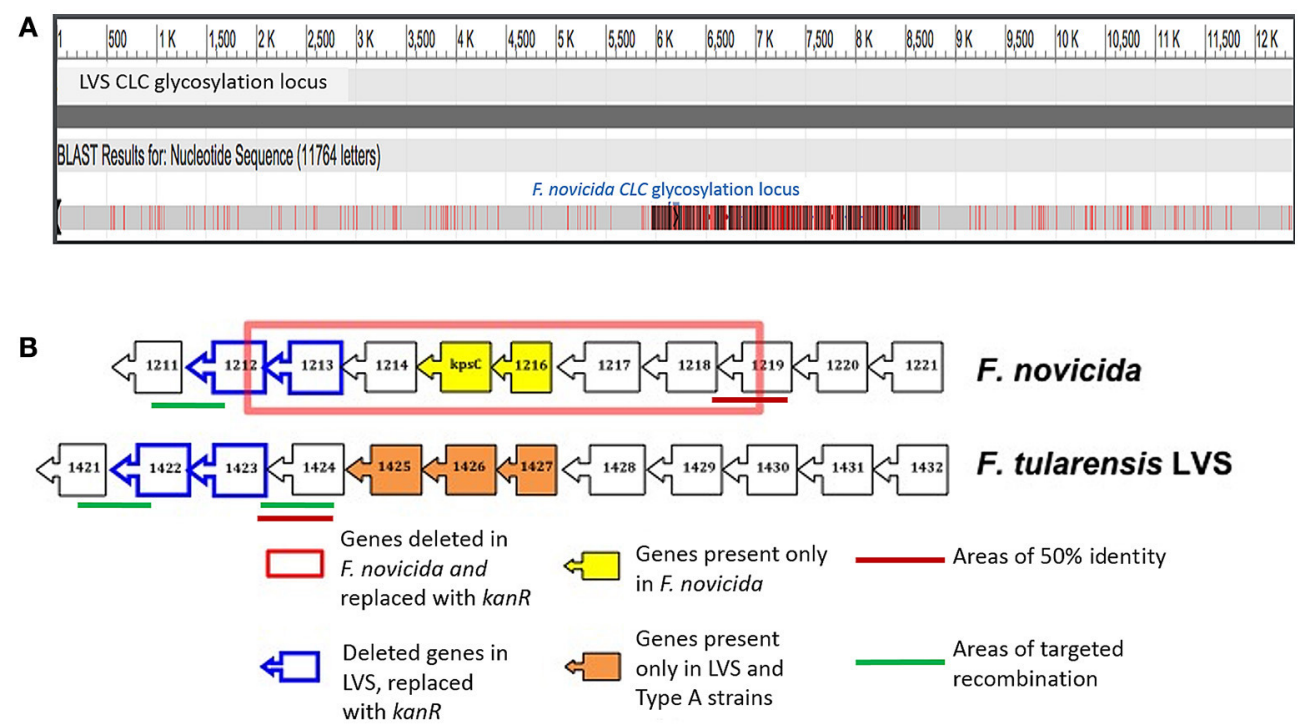

FIGURE 3 | Comparison of the CLC glycosylation loci of LVS and F. novicida. (A) Needleman-Wunsch alignment of the glycosylation loci of LVS with F. novicida showing the regions of dissimilarity in red. (B) Cartoon of the LVS and F. novicida CLC glycosylation loci showing the region deleted in F. novicida $\triangle 1212-1218$ (red box), genes unique to F. novicida and LVS (yellow and orange boxes, respectively), areas targeted for recombination using the same recombination vector used for LVS (green lines), areas of $51 \%$ identity where recombination actually occurred in F. novicida $\Delta 1212-1218$, and genes replaced with kanR gene in LVS and homologous genes targeted for deletion in F. novicida (blue boxes).

mice in groups immunized with 50,1,000, and 10,000 CFU of F. novicida $\Delta$ 1212-1218; all surviving mice showed no clinical symptoms by day 14. All mice immunized with $100 \mathrm{CFU}$ of F. novicida $\Delta 1212-1218$ needed to be euthanized by day 7 postchallenge.

Lungs, liver, and spleen were collected from each mouse post-mortem to determine the bacterial burden of F. novicida U112 in each organ (Figure 8B). No difference in bacterial burden was found in the liver and lungs of immunized mice compared to control mice, but immunized mice had significantly lower bacterial burdens in the spleen compared to control mice $(p<0.0001$ for all immunized groups compared to control). Overall, immunized mice were partially protected from respiratory 
A

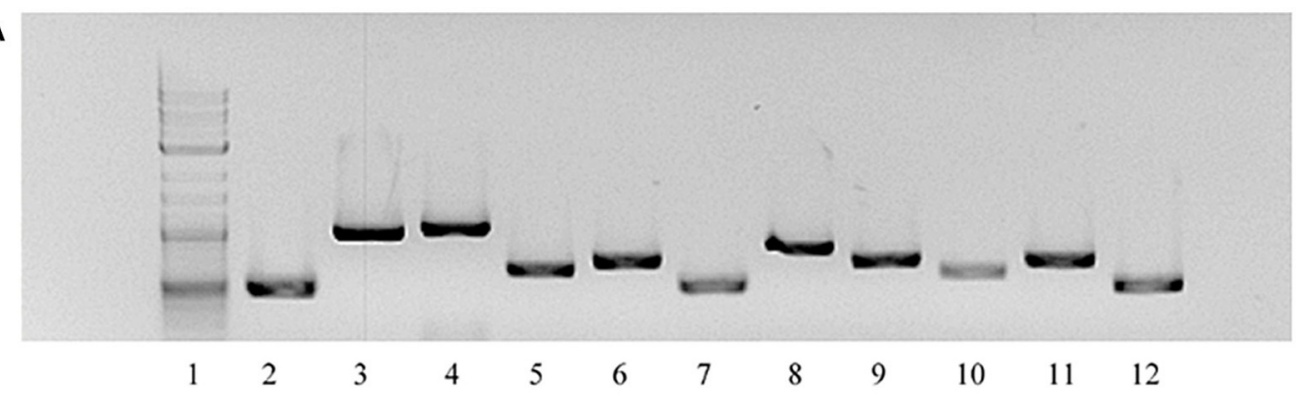

B

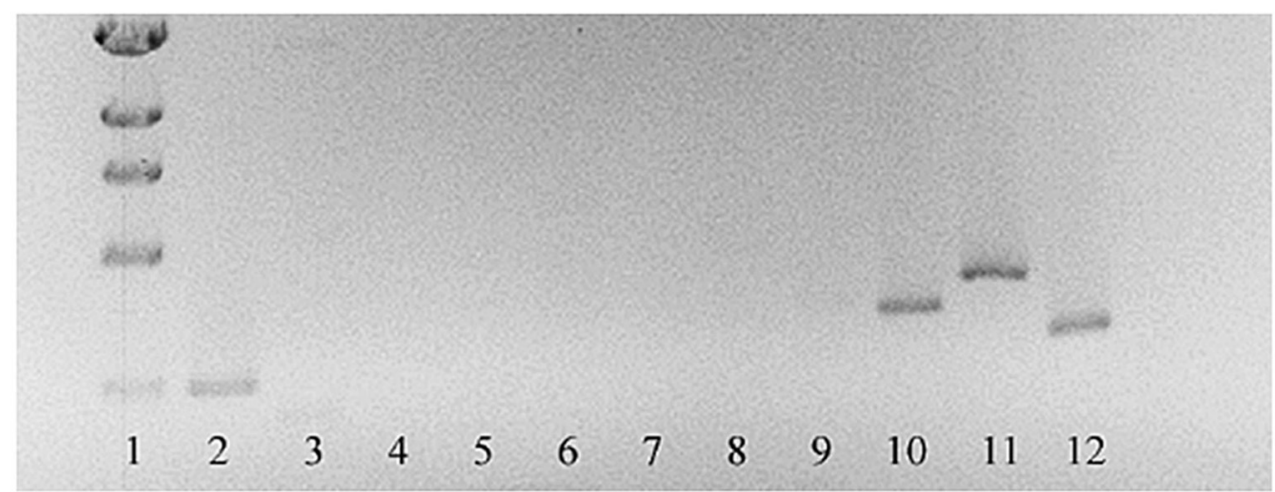

FIGURE 4 | RT-PCR of genes in the glycosylation locus of $F$. novicida $\Delta 1212-1218$ compared to the $F$. novicida parent. RNA was isolated from both $F$. novicida and $F$. novicida $\Delta 1212-1218$ and converted to cDNA. Primers to each gene in the glycosylation locus were used to amplify gene products. Products were successfully amplified for the entire glycosylation locus in F. novicida (A). Gene products were not amplified from FTN_1212 through FTN_1218 in F. novicida $\Delta 1212-1218$ (B). Gene products from FTN_1219 through FTN_1221, also within the glycosylation locus, in F. novicida $\Delta 1212-1218$ were amplified. Lanes: 1, 1-kb ladder; 2-12, transcription products from genes FTN_1211-1221, respectively.

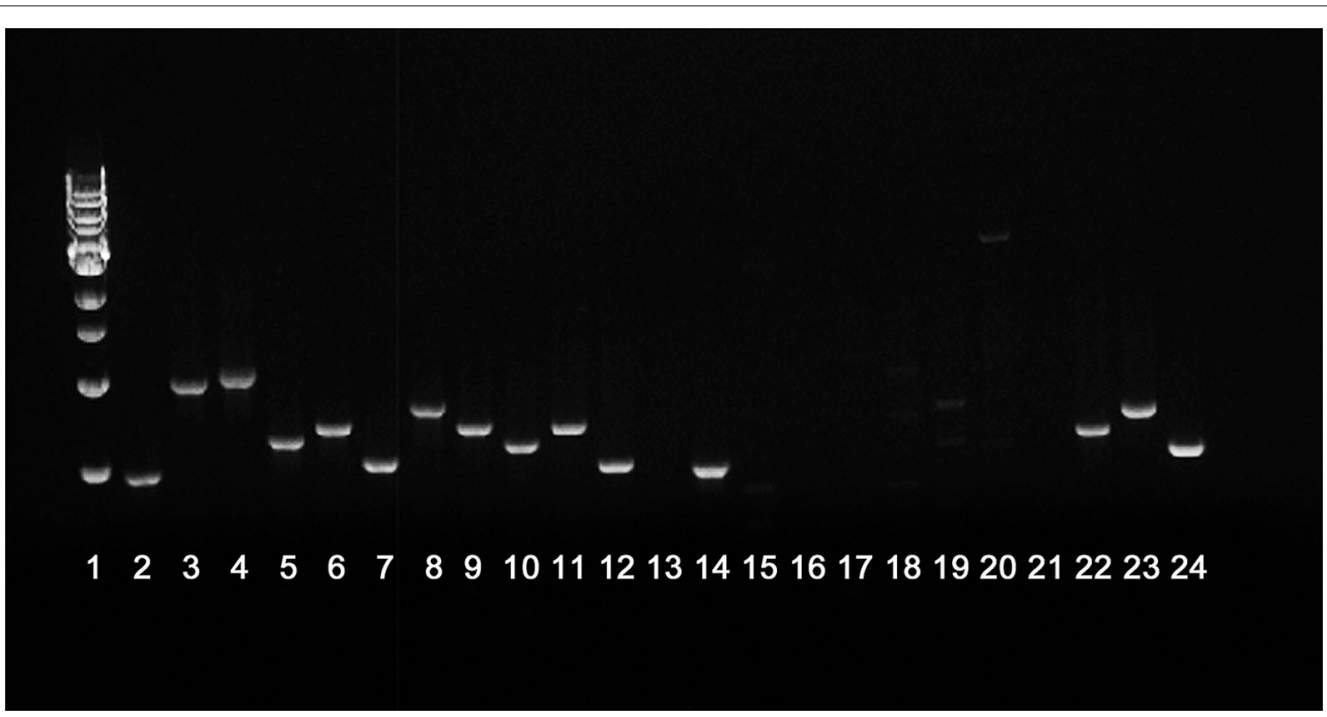

FIGURE 5 | PCR of each open reading frame within the putative CLC glycosylation locus. Lanes 2-12 represent PCR amplification products from parent strain F. novicida U112. Lanes 14-24 represent PCR amplification products from mutant F. novicida $\triangle$ FTN_1212-1218. Lanes: 1, molecular size standards; 2 and 14, FTN_1211; 3 and 15, FTN_1212; 4 and 16, FTN_1213; 5 and 17, FTN_1214; 6 and 18, FTN_ 1215; 7 and 19, FTN_1216; 8 and 20, FTN_1217; 9 and 21,

FTN_1218; 10 and 22, FTN_1219; 11 and 23, FTN_1220; 12 and 24, FTN_1221; 13, blank. 

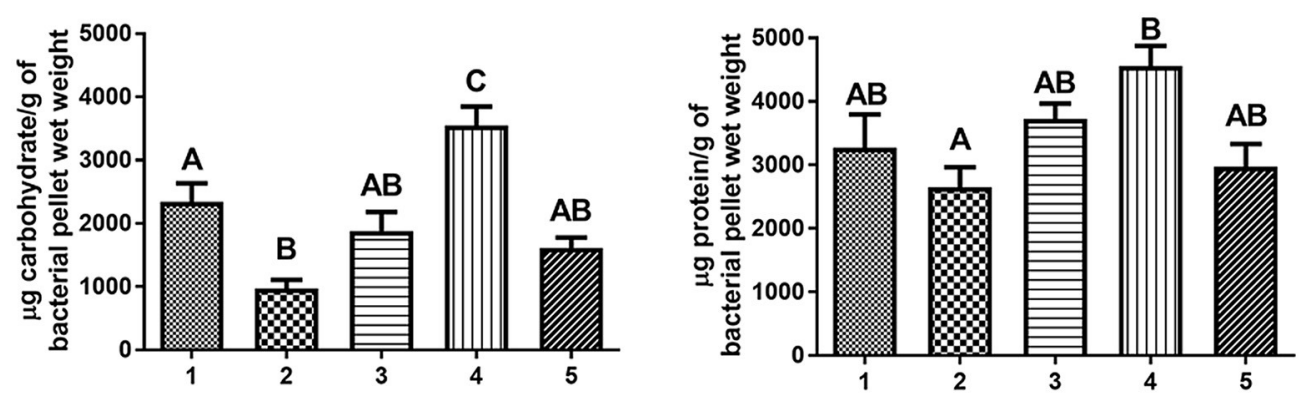

FIGURE 6 | Carbohydrate and protein content of urea extracts from $\boldsymbol{F}$. novicida and LVS strains. All strains were subcultured in CDMB and grown on CDMA at $32^{\circ} \mathrm{C}$ to enhance putative CLC production. The surface material was extracted using $1 \mathrm{M}$ urea, and the crude CLC extracts were analyzed for carbohydrate content by the anthrone assay and for protein content by the BCA assay. The carbohydrate content of the extract from F. novicida $\Delta 11212-1218$ - 10 contained significantly less carbohydrate than that of F. novicida_P10 $(p=0.02)$. The protein content between subcultured strains of $F$. novicida or between strains of LVS was not

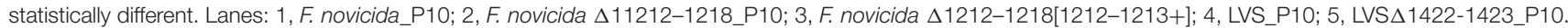
Different letters above the bars indicate significant differences between the means when one-way ANOVA and Tukey's post-hoc were performed ( $p<0.05)$. Identical uppercase letters indicate that there is no significant difference between the means. The value of bar marked with " $A$ " is significantly different from the values of bars marked with "B" or "C." The values of bars marked "AB" are not statistically different from the values of bars marked with "A" or with "B," but are statistically different from a bar marked with "C."
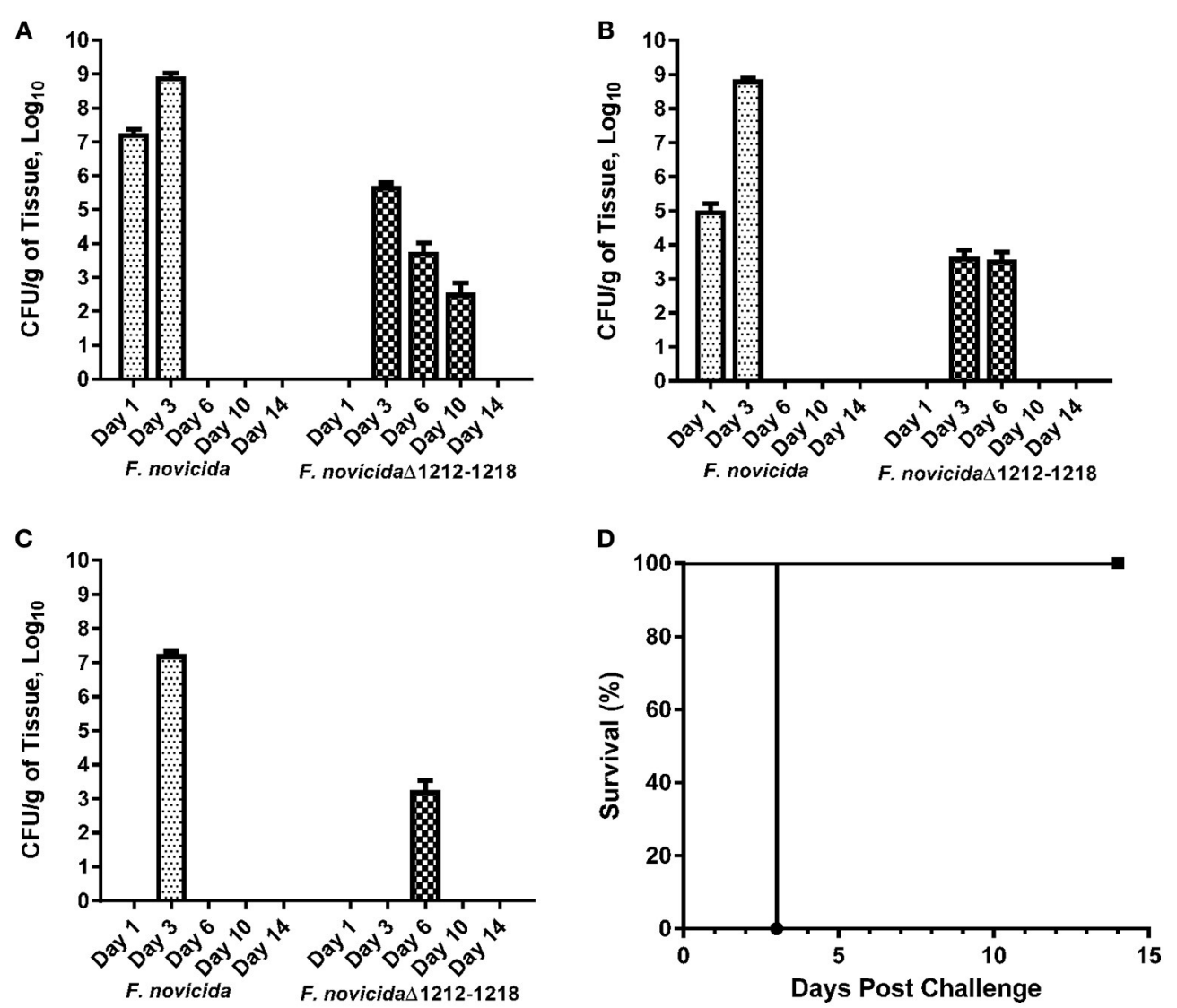

FIGURE 7 | Attenuation of $\boldsymbol{F}$. novicida $\mathbf{\Delta 1 2 1 2 - 1 2 1 8}$ in mice. Mice were inoculated with 1000 CFU of wild-type F. novicida and F. novicida $\Delta 1212-1218$ IN, followed by euthanasia on days 1, 3, 6, 10, and 14. The bacterial burden in the lungs (A), spleen (B), and liver (C) were determined by viable plate counts. The bars represent the mean bacterial burden \pm the SEM for F. novicida (dotted bar) and F. novicida $\Delta 1212-1218$ (checkered bar). All mice inoculated with $F$. novicida ( $\bullet$ ) needed to be euthanized by day 3. All mice inoculated with F. novicida $\Delta 1212-1218$ cleared the bacterial infection by day $10-14$ (D). F. novicida $\Delta 1212-1218$ ( was attenuated in mice IN at a dose of at least 10,000 CFU and infection caused minimal to no signs of clinical illness. 

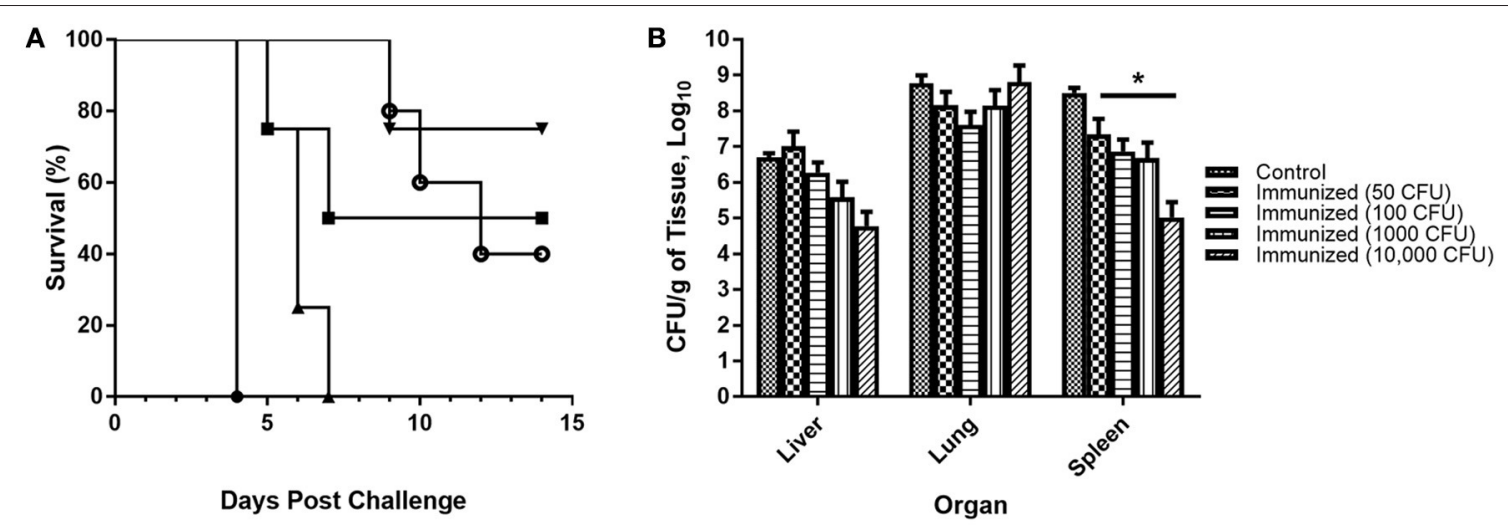

FIGURE 8 | Protection of mice immunized with $F$. novicida $\Delta$ 1212-1218 against IN challenge with wildtype $\boldsymbol{F}$. novicida. (A) BALB/c mice were immunized IN with varying doses of F. novicida $\Delta 1212-1218$ (50 CFU, $\mathbf{\square} ; 100 \mathrm{CFU}, \mathbf{\Lambda} ; 1000 \mathrm{CFU}, \mathbf{v}$ and 10,000 CFU, o) or with PBS (•). Six weeks after immunization the mice were challenged IN with 1,000 CFU of F. novicida U112. Control mice immunized with PBS needed to be euthanized by day 4 . Some of the mice in each group immunized with $50,1,000$, or 10,000 CFU of $F$. novicida $\Delta 1212-1218$ survived until day 14 post-challenge, which was statistically significant $(p<0.001)$ compared to the control group. (B) Bacterial numbers in the liver, lungs, and spleen were determined after euthanasia. All groups of immunized mice had significantly lower bacterial burdens in the spleen compared to control mice $\left({ }^{*} p<0.0001\right)$.
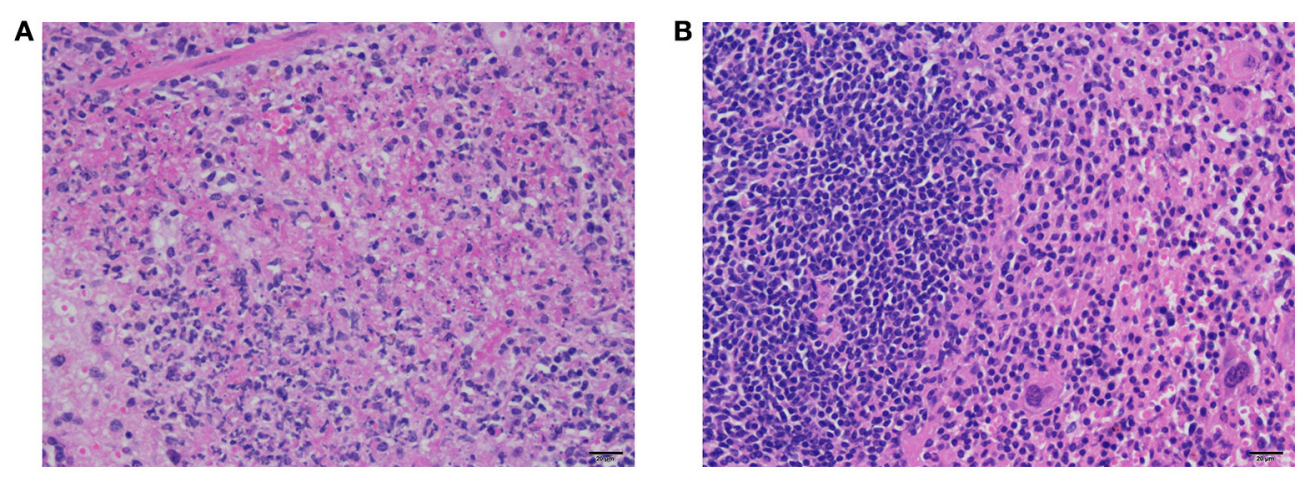

FIGURE 9 | Histopathology of spleens of immunized mice and control mice after challenge with $\boldsymbol{F}$. novicida. There is necrosis and fibrin accumulation surrounded by neutrophils and cellular debris within the red pulp of spleens of control mice (A). In contrast, there is moderate to marked lymphoid hyperplasia characterized by nodular aggregates of lymphocytes, but no evidence of necrosis or neutrophilic inflammation in the spleens of immunized mice (B). H\&E stain, bar = $20 \mu \mathrm{m}$.

challenge with $F$. novicida U112, and the protection was dose dependent.

Severe multifocal to coalescing fibrino-necrotizing splenitis was evident following histopathological examination of postmortem spleens from control mice challenged with $F$. novicida (Figure 9A). However, there was lymphoid hyperplasia and extramedullary hematopoiesis in the spleens of mice immunized with $F$. novicida $\Delta 1212-1218$ and then challenged with $F$. novicida (Figure 9B). There was no evidence of necrosis or neutrophilic inflammation in the spleens of immunized mice, unlike the spleens of control mice.

Spleen lysate cytokine levels were determined as pg of cytokine/mg of total protein \pm the standard error of the mean. Levels of TNF- $\alpha$, INF- $\gamma$, IL-4, and IL-10 were significantly higher in the spleens of challenged control mice than in the spleens of challenged immunized mice (Figures 10A-D; $p$-values for cytokine levels of the group immunized with 10,000 CFU compared to the control mice were $p<0.01,<0.001,<0.01$, and $<0.001$ respectively). There was no significant difference in the levels of IL-12(p70) and IL-2 produced by the spleens of control and immunized mice (Figures 10E,F; $p \geq 0.325$ ), although there was detectably less IL-12(p70) made by mice immunized with $10,000 \mathrm{CFU}$ of the mutant than controls (Figure 10E). GM-CSF levels were only detected in control mice and not in immunized mice, and IL-5 was not detected in any group. Overall, control mice exhibited hypercytokinemia compared to immunized mice.

\section{DISCUSSION}

F. novicida is reported to be non-encapsulated, whereas $F$. tularensis subspecies tularensis and holarctica are described as encapsulated (Sjöstedt, 2005; Elkins et al., 2007; Barker et al., 2009). The presence of a capsule around F. tularensis subspecies tularensis and holarctica is based on the observation 


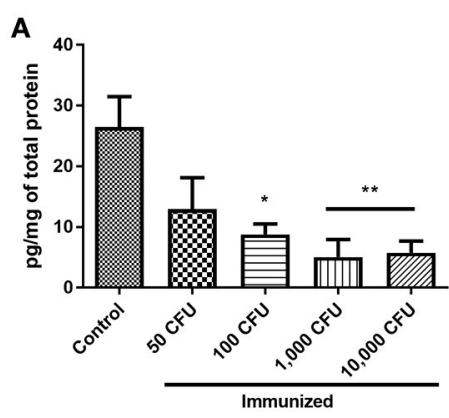

D

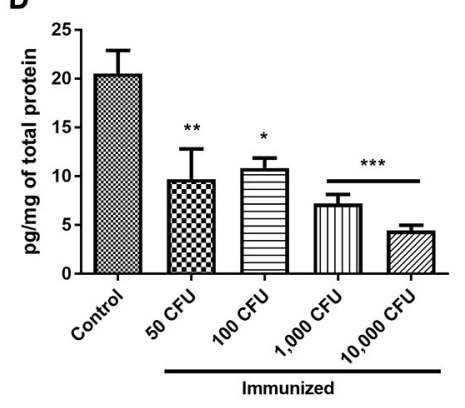

B

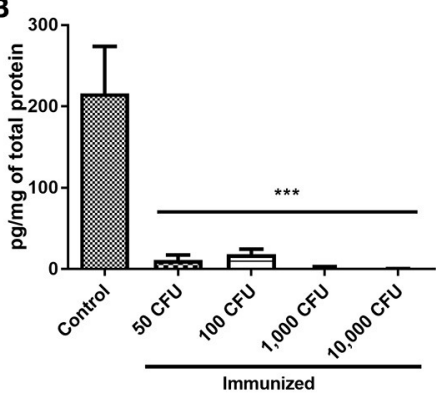

E

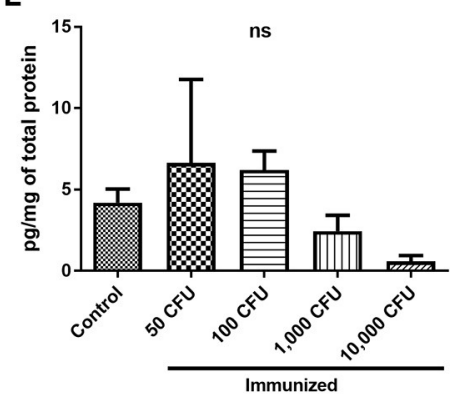

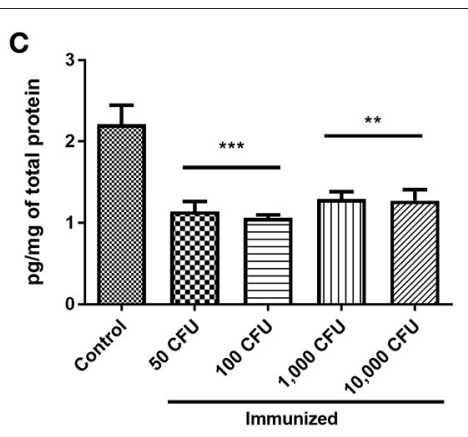

$\mathbf{F}$

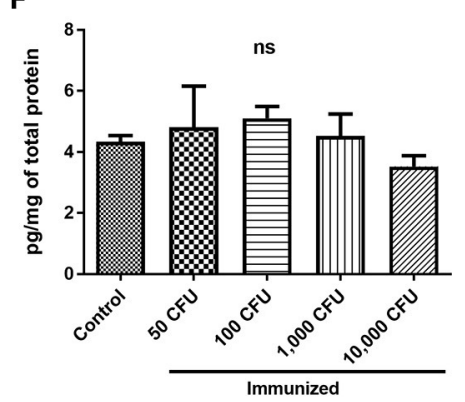

FIGURE 10 | Levels of splenic cytokines in control and immunized mice after challenge. Spleens were harvested after euthanasia and lysed as described in Section Materials and Methods to analyze the levels of splenic cytokines/g of tissue. Cytokine levels were determined by Bio-Plex cytokine assay and reported as $\mu \mathrm{g} / \mathrm{mg}$ of the total protein, determined by BCA. Levels of TNF (A), INF- $\gamma$ (B), IL-4 (C), and IL-10 (D)/g of tissue were significantly lower in mice immunized with $F$. novicida $\Delta 1212-1218$ than control mice. Levels of IL-12 (p70) (E) and IL-2 (F) were not significantly different between groups. ${ }^{*} p<0.05,{ }^{* *} p<0.01,{ }^{* \star *} p<0.001$.

of an electron dense material surrounding the cells by electron microscopy (Sandström et al., 1988; Cherwonogrodzky et al., 1994). Nevertheless, such "encapsulation" is only observed following specific growth conditions. Cherwonogrodzky et al. (1994) reported that subculture of LVS in defined broth medium, such as CDMB, followed by culture for several days on defined medium agar (CDMA), increased the amount of electron dense material surrounding the bacterial cells, and enhanced the virulence of these cells in mice. Previously, we used this serial passage method (adding to it, lowering the culture temperature to $32^{\circ} \mathrm{C}$ ) to confirm that the electron dense material around LVS and type A strains is enhanced during such growth conditions, and that it consists predominately of protein, but also carbohydrate; it is now referred to as CLC (Bandara et al., 2011). F. novicida may have been described as non-encapsulated because it was not grown under the proper conditions to make a similar electron dense material visible. It has not been determined what component(s) of CDM enhance(s) expression of the CLC. However, spermine is present in the CDM and has been shown to induce extensive changes in gene expression, enabling $F$. tularensis to recognize its eukaryotic host environment (Carlson et al., 2009). Furthermore, mutagenesis of the gene putatively responsible for the spermine response attenuated both the LVS and Type A strain SchuS4 in vivo (Russo et al., 2011). Lowering the temperature to $32^{\circ} \mathrm{C}$ may also simulate environmental conditions more closely related to other hosts, such as ticks. Therefore, CDM may simulate signaling by the host environment for $F$. tularensis more closely than other media.
Passage of F. novicida in CDMB, followed by growth at $32^{\circ} \mathrm{C}$ on CDMA, enhanced surface expression of an electron dense material, which was not present around F. novicida cells grown to mid-log phase in shaking broth. This electron dense material appeared similar to the material surrounding both LVS (Bandara et al., 2011) and F. tularensis subspecies tularensis. The F. novicida extracellular material was composed of an array of proteins and a relatively small portion of carbohydrate (consisting of glucose, galactose, and mannose), similar to the CLC of LVS (Bandara et al., 2011). The electrophoretic protein profile of the F. novicida_P10 extract was also similar to the profile of the CLC from LVS and contained components of similar high molecular size. Differential staining further supported that this large molecular size material was glycosylated. Therefore, F. novicida did produce a CLC similar to the CLC of the more virulent subspecies.

A genetic locus with homology to the CLC glycosylation locus of LVS and Type A strains was also identified in F. novicida (Bandara et al., 2011; Thomas et al., 2011). Deletion of two glycosyltransferases (FTL_1423 and FTL_1422; a mannosyltransferase and galactosyltransferase, respectively) eliminated expression of the CLC in LVS. However, deletion of only one of the genes in this locus did not significantly affect glycosylation (Bandara et al., 2011). We have previously reported that deletion of only one glycosyltransferase gene from the capsule locus of Actinobacillus pleuropneumoniae did not completely eliminate capsule expression (Bandara et al., 2003). Furthermore, there was no significant difference in the 
carbohydrate content of the CLC from seven F. novicida TN mutants with one gene inactivated within the glycosylation locus and the parent strain. Therefore, the two genes homologous to those deleted in LVS were targeted for deletion (FTN_1212 and FTN_1213) using the same vector used for mutation of LVS. To our surprise, the allelic exchange process in F. novicida also resulted in loss of upstream genes FTN_1214-1218, but not downstream gene FTN_1211.

It is not clear why so many genes were affected by this allelic exchange procedure, but substantial identity $(51 \%)$ between base pairs at FTN_1219 (the upstream region deleted in F. novicida) and FTL_1424 (the upstream gene in the LVS mutagenesis vector) was identified that may have accounted for the recombination event involving a vector with highly similar DNA of another subspecies. Nonetheless, all of the affected genes were within the glycosylation locus, and deletion of the additional genes should only affect glycosylation of proteins and the CLC.

The content of carbohydrate in crude CLC extracts of the subcultured mutant was significantly reduced compared to the subcultured parent, even though the LPS content was not affected in the mutant. However, the mutations did not significantly affect CLC protein content. Nonetheless, the mutation reduced both the amount of CLC observed, and the association of the CLC proteins with the F. novicida cell surface. When observed by electron microscopy, what little CLC was present around F. novicida $\Delta 1212-1218$ P10 was less adherent, scattered, and away from the bacterial cells, whereas the CLC of wild-type F. novicida_P10 covered the cells and was more directly associated with the bacterial surface. In Haemophilus influenzae, the adhesin HMW1 is glycosylated and this glycosylation is necessary to tether the protein to the bacterial surface: removal of the glycan disassociates the protein from the bacterium (Grass et al., 2003). Therefore, the carbohydrate component of the CLC may also contribute to close association of the CLC proteins to the bacterial surface and contribute to the aggregation of these proteins, as observed by electron microscopy. Enhanced expression of CLC may also promote binding of the bacteria to phagocytic cells and promote bacterial uptake.

Protein glycosylation appears to be widespread in Francisella species. Identical glycans have been identified that modify proteins that include PilA (Egge-Jacobsen et al., 2011), DsbA (Thomas et al., 2011; Balonova et al., 2012), and FTH_0069 (Balonova et al., 2012) in F. tularensis subspecies holarctica and tularensis. The glycan modifying these proteins is a hexasaccharide and the synthesis of this glycan has been linked to genes present in the putative CLC glycosylation locus of subspecies tularensis (Thomas et al., 2011). A multi-method approach of lectin enrichment, lectin blotting, and glycoproteinspecific staining was also used to identify up to 15 putative glycoproteins in $F$. tularensis subspecies holarctica extracts (Balonova et al., 2010). All of these 15 putative glycoproteins have homologs in F. novicida and some of the proteins are putative outer membrane proteins such as FopA and TUL4. Nevertheless, other than PilA, DsbA, and FTH_0069, no other Francisella proteins have been definitively confirmed as glycoproteins.

The differences noted by electron microscopy and virulence between LVS and $F$. novicida mutants lacking the same glycosyltransferases are minimal, but may be related to other mutations in LVS. There are multiple mutations in LVS that may contribute to the bacterium's attenuation in immunocompetent individuals, including multiple hypothetical proteins, outer membrane proteins, metabolism proteins, and more (Rohmer et al., 2006). LVS also contains a truncated version of PilA, which has been shown to be necessary for full virulence in both subspecies holarctica (Forslund et al., 2006) and tularensis (Forslund et al., 2010). In contrast, strain U112 is a wildtype strain of $F$. tularensis and is as virulent for mice as $F$. tularensis type A. In contrast, mice challenged IN with up to 1,000 times the $\mathrm{LD}_{50}$ of $F$. novicida $\Delta 1212-1218$ only developed subclinical infections. During a time course comparing an $F$. novicida $\Delta 1212-1218$ infection with that of an equal dose of the parent, $F$. novicida $\Delta 1212-1218$ did not proliferate in the tissues to the same extent as the wild-type strain, and was below detection level in tissues until day 3 post-challenge, whereas bacterial numbers of $F$. novicida U112 were one or more logs greater. F. novicida $\Delta 1212-1218$ was also unable to disseminate throughout the tissues as effectively as the parent. Therefore, protein glycosylation of the CLC played an important role in the ability of $F$. novicida to disseminate in the mouse, as previously described for LVS (Bandara et al., 2011). The observation that enhanced expression of CLC increases the virulence of F. tularensis (Cherwonogrodzky et al., 1994) and our current and previous findings that inability to glycosylate and fully produce CLC attenuates the bacteria (Bandara et al., 2011), indicates that the CLC contributes to F. tularensis virulence. The mechanism responsible for enhancing virulence is unknown, but may be related to resistance to innate host defenses, promoting macrophage uptake, or promoting escape from the phagosome to the cytosol (Golovliov et al., 2003).

It was not practical to attempt complementation of seven genes in F. novicida $\Delta 1212-1218$. Nonetheless, the mutant was transformed with shuttle vector pFNLTP6 (Bandara et al., 2011) containing the genes targeted for deletion. In data not shown this partially complemented strain contained more carbohydrate than the mutant, less than the parent, but was not significantly different from either. Mice inoculated with 1,000 CFU or more of the mutant expressing FTN_1212 and FTN_1213 demonstrated clinical symptoms that included ruffled fur, reduced activity, and weight loss, but the mice survived for 14 days, unlike mice challenged with the parent. Mice inoculated with 10,000 CFU of this partially complemented mutant had significantly more weight loss than mice inoculated with $10,000 \mathrm{CFU}$ of $F$. novicida $\Delta 1212-1218$ ( $p<0.005$; data not shown). Thus, although as expected complementation of $F$. novicida $\Delta 1212-1218$ with only genes FTN_1212 and FTN_1213 did not restore full virulence to the mutant, these results showed that full glycosylation in $F$. novicida required more than one gene, and partial glycosylation and virulence could be restored despite the lack of several genes. Synthesis of a carbohydrate polymer requires many genes, including transferases, polymerase, phosphorylases, and proteins for export and transport of the polymer across membranes (Whitfield, 2006). BLAST analysis indicated that FTN_12121214 and FTN-1218 are putative glycosyltransferases. FTN_1216 encodes a hypothetical protein of yet unknown function. 
FTN-1215 may encode a protein responsible for capsule export and FTN_1217 for an ATP-binding membrane transporter; both are involved in polysaccharide export. Transport and synthesis of other polysaccharides in F. tularensis, such as LPS and Oantigen capsule, likely also utilize membrane transporters and transferases (the LPS core also contains mannose) that could substitute for some of the missing proteins, enabling partial restoration of CLC glycosylation.

Immunization with $F$. novicida $\Delta 1212-1218$ provided partial protection to mice against IN challenge with the parent strain. This incomplete protection may be due to the inability of F. novicida $\Delta 1212-1218$ to effectively disseminate throughout the host and persist long enough to induce a more protective immune response, or the missing carbohydrate may be an important antigen for protective immunity. F. tularensis and $F$. novicida are facultative intracellular pathogens, and a robust cellular immune response is necessary to effectively clear the infection (Baron et al., 2007; Pechous et al., 2009; Shen et al., 2010). Immunodominant antigens such as the $\mathrm{O}$-antigen provide partial protection against aerosolized challenge with virulent Type B strains, but not Type A strains (Conlan et al., 2002). Immunization of mice with recombinant FopA enclosed in liposomes can afford partial protection against challenge with LVS, but not against SchuS4 (Hickey et al., 2011). These studies suggest that humoral immunity may play an ancillary role in protection against $F$. tularensis. The disruption of the CLC glycan may result in instability of surface antigens surrounding the bacterium resulting in the loss of important antigenic epitopes necessary to stimulate supportive humoral immunity.

In mice, outward clinical signs of tularemia are delayed 2-3 days following infection with Francisella, but the disease quickly progresses and becomes lethal (Elkins et al., 2007; Mares et al., 2008; Cowley and Elkins, 2011). The pathology of tularemia is largely due to tissue damage following severe inflammation and hypercytokinemia that occurs after Francisella has replicated extensively (Mares et al., 2008; Sharma et al., 2009a,b, 2011). In this study, control mice infected with $F$. novicida did not show clinical signs until $\sim 48 \mathrm{~h}$ after infection and became moribund between 72 and $96 \mathrm{~h}$ post-infection. Disease in the challenged, immunized mice did not advance as rapidly as in the control mice, and the infection in mice challenged with $F$. novicida $\Delta 1212-1218$ was subclinical. Sharma et al. (2009a,b) reported that mice challenged with $F$. novicida IN become severely septic and hypercytokinemic, whereas mice challenged with a $F$. novicida mutant lacking a $58-\mathrm{kDa}$ protein produce lower levels of pro-inflammatory cytokines and do not succumb to disease. Mice immunized with $F$. novicida $\Delta 1212-1218$ and then challenged with the parent also exhibit reduced levels of proinflammatory cytokines, such as TNF- $\alpha$, compared to control mice (Sharma et al., 2009a). The level of tissue destruction in the lungs correlates with the levels of pro-inflammatory cytokines; the hypercytokinemic control mice exhibit more severe tissue destruction than the immunized mice after challenge (Sharma et al., 2009a). Our results were similar to those of Sharma et al. (2009a) in regard to differences in cytokine responses between immunized and control mice. Immunized mice from both studies produced significantly less TNF- $\alpha$, IL-10, and GM-CSF after challenge than control mice after challenge. The spike in TNF$\alpha$ that precedes morbidity may be more detrimental to the host and contribute to sepsis instead of effectively controlling the bacterial infection (Mares et al., 2008; Sharma et al., 2009a,b, 2011). Bakshi et al. showed that immunization with an attenuated LVS stain, sodB $B_{F T}$, results in a more controlled release of pro-inflammatory cytokines after challenge than unimmunized control mice (Bakshi et al., 2008). Higher production of proinflammatory cytokines in mice correlates with greater amounts of inflammation and tissue destruction; a delayed response in cytokine production followed by massive up-regulation is a sign of severe tularemia (Metzger et al., 2007; Bakshi et al., 2008). In our study, unlike control mice, mice inoculated with the mutant were not hypercytokinemic after challenge and the spleens of these mice did not exhibit the same level of inflammation and tissue destruction as the spleens of mice inoculated with the parent. Although, immunization of mice with the mutant was not fully protective, the partial protection afforded may be attributed to a more regulated immune response in immunized mice than in control mice after challenge. Interferon gamma (IFN- $\gamma$ ) has been implicated as essential for controlling the replication of F. tularensis during the initial infection. Both Sharma et al. (2009a,b) and Bakshi et al. (2006) reported that immunized mice surviving a lethal challenge exhibit a significant increase in IFN- $\gamma$ compared to controls after infection, followed by a return to baseline levels. In this study, the spleens of immunized mice did not contain significantly higher levels of IFN- $\gamma$ than control mice. The lack of enhanced expression of IFN- $\gamma$ in mice immunized with $F$. novicida $\Delta 1212-1218$ may explain the lack of full protection following challenge with the parent. The $\mathrm{LD}_{50}$ of F. novicida for mice by the respiratory route is $<10$ CFUs (Kieffer et al., 2003; Lauriano et al., 2004; Cong et al., 2009). Therefore, it was not possible to compare the immune response of mice immunized with the mutant to that of a sublethal dose of the parent.

In summary, we have shown that, as for $F$. tularensis, $F$. novicida produced a CLC when grown under conditions that enhanced expression of the electron dense CLC in LVS. The mixture of glycosylated proteins in the F. tularensis CLC have been partially identified (manuscript in preparation). Furthermore, the use of F. novicida and the immense transposon library available may further aid in identifying these proteins and the role of CLC in pathogenesis. Loss of surface protein glycosylation and the deficiency of surface-associated CLC on the bacteria attenuated F. novicida and LVS in a mouse model, and such mutants conferred partial protective immunity against challenge with virulent strains. Mutagenesis of these glycosyltransferase genes in a Type A strain of $F$. tularensis is in progress to determine if such a mutant would also be attenuated and induce protective immunity against type A challenge.

\section{ETHICS STATEMENT}

This study was carried out in accordance with the recommendations of the U.S. Government Principles for the Utilization and Care of Vertebrate Animals Used in Testing, 
Research and Training, The Animal Welfare Act, The Public Health Service Policy on Humane Care and Use of Laboratory Animals, and Virginia Tech Policies Governing the Use of Animals in Research and Teaching, by the Virginia Tech Institutional Animal Care and Use Committee. The protocol was approved by the Virginia Tech Institutional Animal Care and Use Committee; Assurance number A-3208-01, expiration date 7/31/2017.

\section{AUTHOR CONTRIBUTIONS}

KF conceived and performed most of the experiments, wrote the initial draft of the manuscript, contributed to revisions, and $\mathrm{read} / \mathrm{edited}$ the final draft. AC performed some experiments, wrote part of the manuscript, and read/edited the final draft. NM contributed to generating the allelic exchange mutant, wrote part of the manuscript, and read/edited the final draft. TC performed the clinical pathology and read/edited the final draft. TI conceived the experiments, revised the manuscript, and carried out editing of the final draft.

\section{ACKNOWLEDGMENTS}

The authors thank Kathy Lowe at the VMCVM Morphology Lab for her technical assistance with microscopy and the animal care staff at the Center of Molecular Medicine and

\section{REFERENCES}

Altschul, S. F., Gish, W., Miller, W., Myers, E. W., and Lipman, D. J. (1990). Basic local alignment search tool. J. Mol. Biol. 215, 403-410. doi: 10.1016/S0022-2836(05)80360-2

Apicella, M. A., Post, D. M., Fowler, A. C., Jones, B. D., Rasmussen, J. A., Hunt, J. R., et al. (2010). Identification, characterization and immunogenicity of an Oantigen capsular polysaccharide of Francisella tularensis. PLOS ONE 5:e11060. doi: 10.1371/journal.pone.0011060

Bakshi, C. S., Malik, M., Mahawar, M., Kirimanjeswara, G. S., Hazlett, K. R., Palmer, L. E., et al. (2008). An improved vaccine for prevention of respiratory tularemia caused by Francisella tularensis SchuS4 strain. Vaccine 26, 5276-5288. doi: 10.1016/j.vaccine.2008.07.051

Bakshi, C. S., Malik, M., Regan, K., Melendez, J. A., Metzger, D. W., Pavlov, V. M., et al. (2006). Superoxide dismutase B gene (sodB)-deficient mutants of Francisella tularensis demonstrate hypersensitivity to oxidative stress and attenuated virulence. J. Bacteriol. 188, 6443-6448. doi: 10.1128/JB.00266-06

Balonova, L., Hernychova, L., Mann, B. F., Link, M., Bilkova, Z., Novotny, M. V., et al. (2010). Multimethodological approach to identification of glycoproteins from the proteome of Francisella tularensis, an intracellular microorganism. J. Proteome Res. 9, 1995-2005. doi: 10.1021/pr9011602

Balonova, L., Mann, B. F., Cerveny, L., Alley, W. R. Jr., Chovancova, E., Forslund, A. L., et al. (2012). Characterization of protein glycosylation in Francisella tularensis subsp. holarctica: identification of a novel glycosylated lipoprotein required for virulence. Mol. Cell. Proteomics 11:M111.015016. doi: 10.1074/mcp.M111.015016

Bandara, A. B., Champion, A. E., Wang, X., Berg, G., Apicella, M. A., McLendon, M., et al. (2011). Isolation and mutagenesis of a capsule-like complex (CLC) from Francisella tularensis, and contribution of the CLC to F. tularensis virulence in mice. PLoS ONE 6:e19003. doi: 10.1371/journal.pone.0019003

Bandara, A. B., Lawrence, M. L., Veit, H. P., and Inzana, T. J. (2003). Association of Actinobacillus pleuropneumoniae capsular polysaccharide with virulence in pigs. Infect. Immun. 71, 3320-3328. doi: 10.1128/IAI.71.6.3320-3328.2003
Infectious Diseases (CMMID) for their assistance in caring for and handling the animals used in this project. We would like to thank Dr. Parastoo Azadi and colleagues at the University of Georgia Complex Carbohydrate Research Center for glycose identification of the F. novicida CLC. The following reagents were obtained through the NIH Biodefense and Emerging Infections Research Resources Repository, NIAID, NIH: F. tularensis subsp. novicida, "Two-Allele" Transposon Mutant Library, Plate 3 (tnfn1_pw060323p03q152; $\Delta$ FTN_1213), NR-8037; Plate 5 (tnfn1_pw060323p05q162; $\Delta$ FTN_1212 and tnfn1_pw060323p05q110; $\Delta$ FTN_1215), NR-8039; Plate 7 (tnfn1_pw060323p07q127; $\Delta$ FTN_1218), NR-8041; Plate 14 (tnfn1_pw060328p06q149; $\Delta$ FTN_1214), NR-8048; Plate 19 (tnfn1_pw060418p03q107; $\Delta$ FTN_1217), NR-8053; and Plate 28 (tnfn1_pw060420p04q184; $\Delta$ FTN_1216), NR-8062. This work was supported by the Tyler J. and Frances F. Young Foundation, the Virginia-Maryland College of Veterinary Medicine, the Stamps Family Charitable Foundation, and the Department of Energy-funded (DF-FG02-93ER-20097) Center for Plant and Microbial Complex Carbohydrates.

\section{SUPPLEMENTARY MATERIAL}

The Supplementary Material for this article can be found online at: https://www.frontiersin.org/articles/10.3389/fmicb. 2017.00935/full\#supplementary-material

Barker, J. H., McCaffrey, R. L., Baman, N. K., Allen, L. A., Weiss, J. P., and Nauseef, W. M. (2009). The role of complement opsonization in interactions between $F$. tularensis subsp. novicida and human neutrophils. Microbes Infect. 11, 762-769. doi: 10.1016/j.micinf.2009.04.016

Baron, S. D., Singh, R., and Metzger, D. W. (2007). Inactivated Francisella tularensis live vaccine strain protects against respiratory tularemia by intranasal vaccination in an immunoglobulin A-dependent fashion. Infect. Immun. 75, 2152-2162. doi: 10.1128/IAI.01606-06

Carlson, P. E. Jr., Horzempa, J., O’Dee, D. M., Robinson, C. M., Neophytou, P., Labrinidis, A., et al. (2009). Global transcriptional response to spermine, a component of the intramacrophage environment, reveals regulation of Francisella gene expression through insertion sequence elements. J. Bacteriol. 191, 6855-6864. doi: 10.1128/JB.00995-09

Centers for Disease Control and Prevention and Department of Health and Human Services (2012). Possession, use, and transfer of select agents and toxins; biennial review; final rule. Fed. Regist. 77, 61083-61115.

Chamberlain, R. E. (1965). Evaluation of live tularemia vaccine prepared in a chemically defined medium. Appl. Microbiol. 13, 232-235.

Champion, A., Mohapatra, N., Bandara, A., Twine, S., and Inzana, T. J. (2015). "The capsule-like complex (CLC) of type A Francisella tularensis may be derived from outer membrane vesicles, but glycosylation of the CLC is not required for virulence and is not protective," in 115th General Meeting of the American Society for Microbiology (New Orleans, LA: American Society for Microbiology).

Cherwonogrodzky, J. W., Knodel, M. H., and Spence, M. R. (1994). Increased encapsulation and virulence of Francisella tularensis live vaccine strain (LVS) by subculturing on synthetic medium. Vaccine 12, 773-775. doi: 10.1016/0264-410X(94)90284-4

Cong, Y., Yu, J. J., Guentzel, M. N., Berton, M. T., Seshu, J., Klose, K. E., et al. (2009). Vaccination with a defined Francisella tularensis subsp. novicida pathogenicity island mutant (DeltaiglB) induces protective immunity against homotypic and heterotypic challenge. Vaccine 27, 5554-5561. doi: 10.1016/j.vaccine.2009.07.034 
Conlan, J. W., Shen, H., Webb, A., and Perry, M. B. (2002). Mice vaccinated with the O-antigen of Francisella tularensis LVS lipopolysaccharide conjugated to bovine serum albumin develop varying degrees of protective immunity against systemic or aerosol challenge with virulent type A and type B strains of the pathogen. Vaccine 20, 3465-3471. doi: 10.1016/S0264-410X(02)00345-6

Conlan, W. J., and Oyston, P. C. (2007). Vaccines against Francisella tularensis. Ann. N. Y. Acad. Sci. 1105, 325-350. doi: 10.1196/annals. 1409.012

Cowley, S. C., and Elkins, K. L. (2011). Immunity to Francisella. Front. Microbiol. 2:26. doi: $10.3389 /$ fmicb.2011.00026

Dennis, D. T., Inglesby, T. V., Henderson, D. A., Bartlett, J. G., Ascher, M. S., Eitzen, E., et al. (2001). Tularemia as a biological weapon: medical and public health management. JAMA 285, 2763-2773. doi: 10.1001/jama.285.21.2763

Egge-Jacobsen, W., Salomonsson, E. N., Aas, F. E., Forslund, A. L., Winther-Larsen, H. C., Maier, J., et al. (2011). O-linked glycosylation of the PilA pilin protein of Francisella tularensis: identification of the endogenous protein-targeting oligosaccharyltransferase and characterization of the native oligosaccharide. J. Bacteriol. 193, 5487-5497. doi: 10.1128/JB.00383-11

Elkins, K. L., Cowley, S. C., and Bosio, C. M. (2007). Innate and adaptive immunity to Francisella. Ann. N. Y. Acad. Sci. 1105, 284-324. doi: 10.1196/annals.1409.014

Forslund, A. L., Kuoppa, K., Svensson, K., Salomonsson, E., Johansson, A., Bystrom, M., et al. (2006). Direct repeat-mediated deletion of a type IV pilin gene results in major virulence attenuation of Francisella tularensis. Mol. Microbiol. 59, 1818-1830. doi: 10.1111/j.1365-2958.2006.05061.x

Forslund, A. L., Salomonsson, E. N., Golovliov, I., Kuoppa, K., Michell, S., Titball, R., et al. (2010). The type IV pilin, PilA, is required for full virulence of Francisella tularensis subspecies tularensis. BMC Microbiol. 10:227. doi: 10.1186/1471-2180-10-227

Frank, D. W., and Zahrt, T. C. (2007). Genetics and genetic manipulation in Francisella tularensis. Ann. N. Y. Acad. Sci. 1105, 67-97. doi: 10.1196/annals.1409.008

Gallagher, L. A., McKevitt, M., Ramage, E. R., and Manoil, C. (2008). Genetic dissection of the Francisella novicida restriction barrier. J. Bacteriol. 190, 7830-7837. doi: 10.1128/JB.01188-08

Gallagher, L. A., Ramage, E., Jacobs, M. A., Kaul, R., Brittnacher, M., and Manoil, C. (2007). A comprehensive transposon mutant library of Francisella novicida, a bioweapon surrogate. Proc. Natl. Acad. Sci. U.S.A. 104, 1009-1014. doi: 10.1073/pnas.0606713104

Golovliov, I., Baranov, V., Krocova, Z., Kovarova, H., and Sjostedt, A. (2003). An attenuated strain of the facultative intracellular bacterium Francisella tularensis can escape the phagosome of monocytic cells. Infect. Immun. 71, 5940-5950. doi: 10.1128/IAI.71.10.5940-5950.2003

Grass, S., Buscher, A. Z., Swords, W. E., Apicella, M. A., Barenkamp, S. J., Ozchlewski, N., and St Geme, J. W. III. (2003). The Haemophilus influenzae HMW1 adhesin is glycosylated in a process that requires HMW1C and phosphoglucomutase, an enzyme involved in lipooligosaccharide biosynthesis. Mol. Microbiol. 48, 737-751. doi: 10.1046/j.1365-2958.2003.03450.x

Gunn, J. S., and Ernst, R. K. (2007). The structure and function of Francisella lipopolysaccharide. Ann. N. Y. Acad. Sci. 1105, 202-218. doi: 10.1196/annals.1409.006

Hickey, A. J., Hazlett, K. R., Kirimanjeswara, G. S., and Metzger, D. W. (2011). Identification of Francisella tularensis outer membrane protein A (FopA) as a protective antigen for tularemia. Vaccine 29, 6941-6947. doi: 10.1016/j.vaccine.2011.07.075

Inzana, T. J., Glindemann, G. E., Snider, G., Gardner, S., Crofton, L., Byrne, B., et al. (2004). Characterization of a wildtype strain of Francisella tularensis isolated from a cat. J. Vet. Diagn. Invest. 16, 374-381. doi: 10.1177/104063870401600502

Jones, B. D., Faron, M., Rasmussen, J. A., and Fletcher, J. R. (2014). Uncovering the components of the Francisella tularensis virulence stealth strategy. Front. Cell. Infect. Microbiol. 4:32. doi: 10.3389/fcimb.2014.00032

Keim, P., Johansson, A., and Wagner, D. M. (2007). Molecular epidemiology, evolution, and ecology of Francisella. Ann. N. Y. Acad. Sci. 1105, 30-66. doi: 10.1196/annals.1409.011

Kieffer, T. L., Cowley, S., Nano, F. E., and Elkins, K. L. (2003). Francisella novicida LPS has greater immunobiological activity in mice than F. tularensis LPS, and contributes to F. novicida murine pathogenesis. Microbes Infect 5, 397-403. doi: 10.1016/S1286-4579(03)00052-2
Kingry, L. C., and Petersen, J. M. (2014). Comparative review of Francisella tularensis and Francisella novicida. Front. Cell. Infect. Microbiol. 4:35. doi: $10.3389 /$ fcimb. 2014.00035

Larsson, P., Oyston, P. C., Chain, P., Chu, M. C., Duffield, M., Fuxelius, H. H., et al. (2005). The complete genome sequence of Francisella tularensis, the causative agent of tularemia. Nat. Genet. 37, 153-159. doi: 10.1038/ng1499

Lauriano, C. M., Barker, J. R., Yoon, S. S., Nano, F. E., Arulanandam, B. P., Hassett, D. J., et al. (2004). MglA regulates transcription of virulence factors necessary for Francisella tularensis intraamoebae and intramacrophage survival. Proc. Natl. Acad. Sci. U.S.A. 101, 4246-4249. doi: 10.1073/pnas.0307690101

Li, J., Ryder, C., Mandal, M., Ahmed, F., Azadi, P., Snyder, D. S., et al. (2007). Attenuation and protective efficacy of an O-antigen-deficient mutant of Francisella tularensis LVS. Microbiol 153, 3141-3153. doi: 10.1099/mic.0.2007/006460-0

LoVullo, E. D., Sherrill, L. A., and Pavelka, M. S. Jr. (2009). Improved shuttle vectors for Francisella tularensis genetics. FEMS Microbiol. Lett. 291, 95-102. doi: 10.1111/j.1574-6968.2008.01440.x

Mares, C. A., Ojeda, S. S., Morris, E. G., Li, Q., and Teale, J. M. (2008). Initial delay in the immune response to Francisella tularensis is followed by hypercytokinemia characteristic of severe sepsis and correlating with upregulation and release of damage-associated molecular patterns. Infect. Immun. 76, 3001-3010. doi: 10.1128/IAI.00215-08

Merkle, R. K., and Poppe, I. (1994). Carbohydrate composition analysis of glycoconjugates by gas-liquid chromatography/mass spectrometry. Methods Enzymol. 230, 1-15. doi: 10.1016/0076-6879(94)30003-8

Metzger, D. W., Bakshi, C. S., and Kirimanjeswara, G. (2007). Mucosal immunopathogenesis of Francisella tularensis. Ann. N. Y. Acad. Sci. 1105, 266-283. doi: 10.1196/annals.1409.007

Modise, T., Ryder, C., Mane, S. P., Bandara, A. B., Jensen, R. V., and Inzana, T. J. (2012). Genomic comparison between a virulent type Al strain of Francisella tularensis and its attenuated O-antigen mutant. J. Bacteriol. 194, 2775-2776. doi: 10.1128/JB.00152-12

Pechous, R. D., McCarthy, T. R., and Zahrt, T. C. (2009). Working toward the future: insights into Francisella tularensis pathogenesis and vaccine development. Microbiol. Mol. Biol. Rev. 73, 684-711. doi: 10.1128/MMBR.00028-09

Raynaud, C., Meibom, K. L., Lety, M. A., Dubail, I., Candela, T., Frapy, E., et al. (2007). Role of the wbt locus of Francisella tularensis in lipopolysaccharide O-antigen biogenesis and pathogenicity. Infect. Immun. 75, 536-541. doi: 10.1128/IAI.01429-06

Rohmer, L., Brittnacher, M., Svensson, K., Buckley, D., Haugen, E., Zhou, Y., et al. (2006). Potential source of Francisella tularensis live vaccine strain attenuation determined by genome comparison. Infect. Immun. 74, 6895-6906. doi: 10.1128/IAI.01006-06

Rowe, H. M., and Huntley, J. F. (2015). From the outside-in: the Francisella tularensis envelope and virulence. Front. Cell. Infect. Microbiol. 5:94. doi: 10.3389/fcimb.2015.00094

Russo, B. C., Horzempa, J., O’Dee, D. M., Schmitt, D. M., Brown, M. J., Carlson, P. E. Jr., et al. (2011). A Francisella tularensis locus required for spermine responsiveness is necessary for virulence. Infect. Immun. 79, 3665-3676. doi: 10.1128/IAI.00135-11

Sandström, G., Löfgren, S., and Tärnvik, A. (1988). A capsule-deficient mutant of Francisella tularensis LVS exhibits enhanced sensitivity to killing but diminished sensitivity to killing by polymorphonuclear leukocytes. Infect. Immun. 56, 1194-1202.

Saslaw, S., Eigelsbach, H. T., Prior, J. A., Wilson, H. E., and Carhart, S. (1961). Tularemia vaccine study. II. Respiratory challenge. Arch. Intern. Med. 107, 702-714. doi: 10.1001/archinte.1961.03620050068007

Scott, T. A., and Melvin, E. H. (1953). Determination of dextran with anthrone. Anal. Chem. 25, 1656-1661. doi: 10.1021/ac60083a023

Sharma, J., Li, Q., Mishra, B. B., Georges, M. J., and Teale, J. M. (2009a). Vaccination with an attenuated strain of Francisella novicida prevents T-cell depletion and protects mice infected with the wild-type strain from severe sepsis. Infect. Immun. 77, 4314-4326. doi: 10.1128/IAI.00654-09

Sharma, J., Li, Q., Mishra, B. B., Pena, C., and Teale, J. M. (2009b). Lethal pulmonary infection with Francisella novicida is associated with severe sepsis. J. Leukoc. Biol. 86, 491-504. doi: 10.1189/jlb.1208728 
Sharma, J., Mares, C. A., Li, Q., Morris, E. G., and Teale, J. M. (2011). Features of sepsis caused by pulmonary infection with Francisella tularensis type A strain. Microb. Pathog. 51, 39-47. doi: 10.1016/j.micpath.2011.03.007

Shen, H., Harris, G., Chen, W., Sjostedt, A., Ryden, P., and Conlan, W. (2010). Molecular immune responses to aerosol challenge with Francisella tularensis in mice inoculated with live vaccine candidates of varying efficacy. PLoS ONE 5:e13349. doi: 10.1371/journal.pone.0013349

Sjöstedt, A. (2005). "Family III Francisellaceae, fam. nov.," in Bergey's Manual of Systematic Bacteriology, 2nd Edn., eds N. R. Krieg, D. J. Brenner and J. T. Staley (New York, NY: Springer), 199-210.

Sjöstedt, A. (2007). Tularemia: history, epidemiology, pathogen physiology, and clinical manifestations. Ann. N. Y. Acad. Sci. 1105, 1-29. doi: 10.1196/annals. 1409.009

Thomas, R. M., Twine, S. M., Fulton, K. M., Tessier, L., Kilmury, S. L., Ding, W., et al. (2011). Glycosylation of DsbA in Francisella tularensis subsp. tularensis. J. Bacteriol. 193, 5498-5509. doi: 10.1128/JB.00438-11
Whitfield, C. (2006). Biosynthesis and assembly of capsular polysaccharides in Escherichia coli. Annu. Rev. Biochem. 75, 39-68. doi: 10.1146/annurev.biochem.75.103004.142545

Conflict of Interest Statement: The authors declare that the research was conducted in the absence of any commercial or financial relationships that could be construed as a potential conflict of interest.

Copyright (C) 2017 Freudenberger Catanzaro, Champion, Mohapatra, Cecere and Inzana. This is an open-access article distributed under the terms of the Creative Commons Attribution License (CC BY). The use, distribution or reproduction in other forums is permitted, provided the original author(s) and the copyright owner are credited and that the original publication in this journal is cited, in accordance with accepted academic practice. No use, distribution or reproduction is permitted which does not comply with these terms. 